\title{
The 1980, 1997 and 1998 Azores earthquakes and some seismo-tectonic implications
}

\author{
J.F. Borges ${ }^{\mathrm{a}, *}$, M. Bezzeghoud ${ }^{\mathrm{a}}$, E. Buforn ${ }^{\mathrm{b}}$, C. Pro $^{\mathrm{c}}$, A. Fitas ${ }^{\mathrm{a}}$ \\ a Departamento de Física e Centro de Geofisica de Évora, University of Évora, Colégio Luis Verney, \\ Rua Romão Ramalho, 59, 7002-554 Évora, Portugal \\ ${ }^{\mathrm{b}}$ Departamento de Geofisica y Meteorología, Fac. CC. Físicas, Universidad Complutense, 28040 Madrid, Spain \\ c Departamento de Física de la Universidad de Extremadura, Mérida, Badajoz, Spain
}

Received 28 August 2005; received in revised form 29 December 2006; accepted 24 January 2007

Available online 14 February 2007

\begin{abstract}
We have studied the focal mechanisms of the 1980, 1997 and 1998 earthquakes in the Azores region from body-wave inversion of digital GDSN (Global Digital Seismograph Network) and broadband data. For the 1980 and 1998 shocks, we have obtained strikeslip faulting, with the rupture process made up of two sub-events in both shocks, with total scalar seismic moments of $1.9 \times 10^{19} \mathrm{Nm}$ $\left(M_{\mathrm{w}}=6.8\right)$ and $1.4 \times 10^{18} \mathrm{Nm}\left(M_{\mathrm{w}}=6.0\right)$, respectively. For the 1997 shock, we have obtained a normal faulting mechanism, with the rupture process made up of three sub-events, with a total scalar seismic moment of $7.7 \times 10^{17} \mathrm{Nm}\left(M_{\mathrm{w}}=5.9\right)$. A common characteristic of these three earthquakes was the shallow focal depth, less than $10 \mathrm{~km}$, in agreement with the oceanic-type crust. From the directivity function of Rayleigh (LR) waves, we have identified the NW-SE plane as the rupture plane for the 1980 and 1998 earthquakes with the rupture propagating to the SE. Slow rupture velocity, about of $1.5 \mathrm{~km} / \mathrm{s}$, has been estimated from directivity function for the 1980 and 1998 earthquakes. From spectral analysis and body-wave inversion, fault dimensions, stress drop and average slip have been estimated. Focal mechanisms of the three earthquakes we have studied, together with focal mechanisms obtained by other authors, have been used in order to obtain a seismotectonic model for the Azores region. We have found different types of behaviour present along the region. It can be divided into two zones: Zone I, from $30^{\circ} \mathrm{W}$ to $27^{\circ} \mathrm{W}$; Zone II, from $27^{\circ} \mathrm{W}$ to $23^{\circ} \mathrm{W}$, with a change in the seismicity and stress direction from Zone I. In Zone I, the total seismic moment tensor obtained corresponded to left-lateral strike-slip faulting with horizontal pressure and tension axes in the E-W and N-S directions, respectively. In Zone II, the total seismic moment tensor corresponded to normal faulting, with a horizontal tension axis trending NE-SW, normal to the Terceira Ridge. The stress pattern for the whole region corresponds to horizontal extension with an average seismic slip rate of $4.4 \mathrm{~mm} / \mathrm{yr}$.
\end{abstract}

(C) 2007 Elsevier B.V. All rights reserved.

Keywords: Azores triple junction; Focal mechanism; Source rupture process; Seismic slip rate

\footnotetext{
* Corresponding author.

E-mail addresses: jborges@uevora.pt (J.F. Borges), ebufornp@fis.ucm.es (E. Buforn).
}

\section{Introduction}

The focal mechanisms of the Azores earthquakes have been the object of several studies: of McKenzie (1972), of López Arroyo and Udías (1972) and of Udías et al. (1976), using first motions of body-waves; and of Grimison and Chen (1988) and of Buforn et al. (1988), 


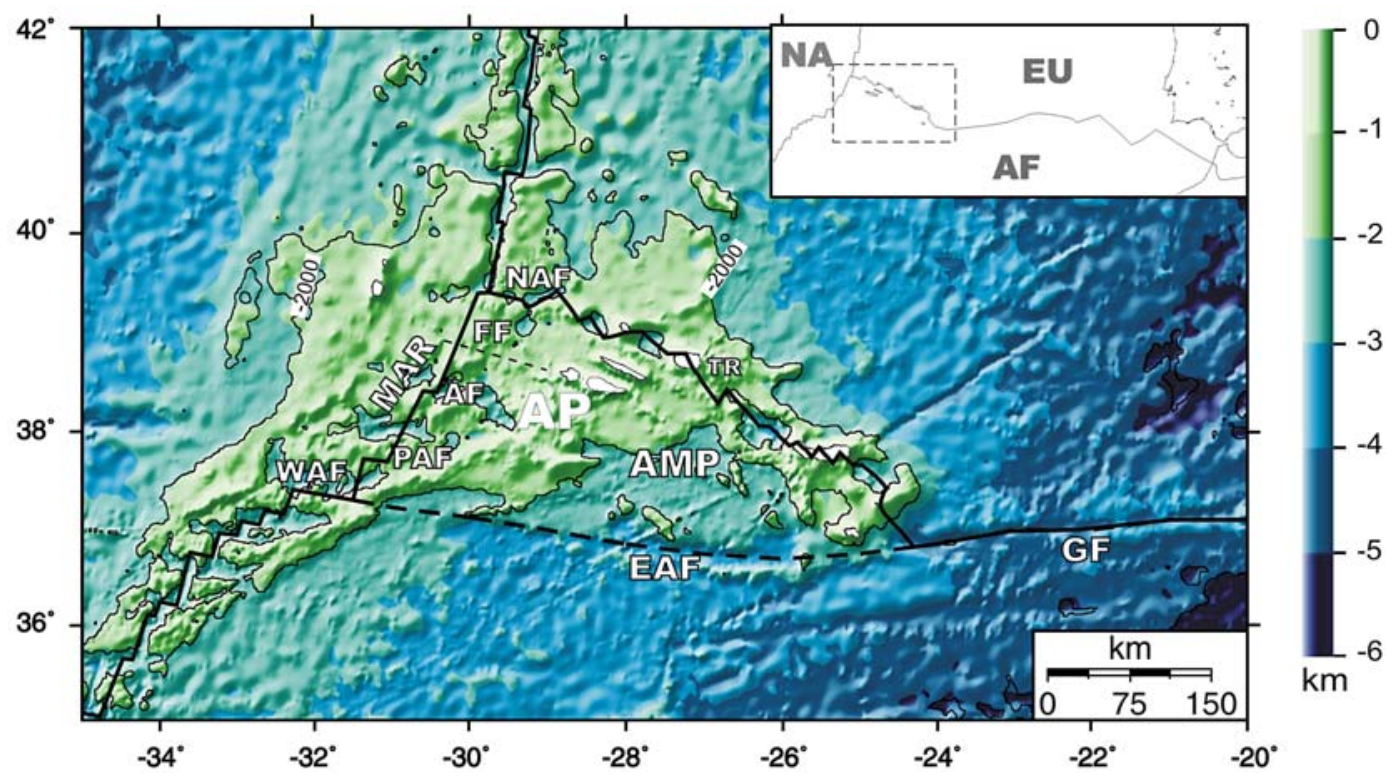

Fig. 1. The main tectonic features for the Azores region, together with the geographical references mentioned in the text. MAR=Mid-Atlantic Ridge; $\mathrm{TR}=$ Terceira Ridge; $\mathrm{NAF}=$ North Azores Fracture Zone; $\mathrm{FF}=$ Faial fracture; $\mathrm{AF}=$ Azores fracture; $\mathrm{PAF}=$ Princess Alice fracture; $\mathrm{WAF}=\mathrm{West}$ Azores fracture; $\mathrm{EAF}=$ East Azores fracture; $\mathrm{GF}=\mathrm{Gloria}$ Fault; $\mathrm{AP}=$ Azores plateau; $\mathrm{NA}=$ North American plate; $\mathrm{EA}=\mathrm{Eurasian}$ plate; $\mathrm{AF}=\mathrm{African}$ plate. The bathymetric lines are taken from the digital bathymetric data set ETOPO2 (U.S. Department of Commerce, NOAA/NGDC, 2001). The tectonic boundaries are taken from Bird (2003; ftp://element.ess.ucla.edu/ PB2002/). The EAF trace is taken from an interpretation of the bathymetry (see text for details).

from first motions and the inversion of body-waves. However, all these studies have used analogical WWSSN (World-Wide Standardized Seismograph Network) data and no later seismological studies have been done. The 27 June $1997\left(M_{\mathrm{w}}=5.9\right)$ and 9 July 1998 $\left(M_{\mathrm{w}}=6.2\right)$ earthquakes were the first occurring in the Azores region to be recorded on broadband digital instruments at teleseismic distances and, for the first time, it has been possible to study these earthquakes using waveform analysis and to obtain detailed information about their source rupture processes.

The Azores triple junction (ATJ), a region where the North American, Eurasian and African lithospheric plates meet, dominates the tectonic setting of the region. The Azores triple junction is located in the western part of the Eurasian-African plate boundary. The region is a zone of anomalously shallow bathymetry, with an approximately triangular form limited by the bathymetric line of $2000 \mathrm{~m}$ (Fig. 1), known as the Azores Plateau (AP) (Lourenço et al., 1998). The Azores plateau is crossed in a NS direction by the Mid-Atlantic Ridge (MAR) and its boundaries are: the magnetic anomaly 6 $(20 \mathrm{Ma})$ in the west; the North Azores Fracture Zone (NAF) with an EW trend, which continues into the Terceira Ridge (TR), trending SE and including the S. Miguel-Terceira-Graciosa, Faial-Pico and S. Jorge alignments, and the East Azores Fracture (EAF) striking
E-W to the south, continuing to the Gloria Fault (GF) (Buforn et al., 1988; Luis et al., 1994). The islands of the Azores Archipelago are located near the limit between Eurasian and African plates, with the exception of Flores and Corvo islands, which are on the North American plate. The Mid-Atlantic Ridge is the dominant feature in this region, with a $\mathrm{N} 10^{\circ}-20^{\circ} \mathrm{E}$ trend. In this area the Mid-Atlantic Ridge flanks show an attenuated roughness when compared to a normal ridge segment (Luis, 1996). The Mid-Atlantic Ridge is offset by five transform faults with a general E-W trend. From north to south, east of the Mid-Atlantic Ridge, they are the North Azores (NAF), Faial (FF), Azores (AF), Princess Alice (PAF) and Pico (PF) fracture zones. In spite of the many international efforts concentrated on the Azores triple junction, the relationship between the mantle processes, the seismic and volcanic activity and the crustal structure are still poorly understood.

The Azores plateau, formed by abnormally thick oceanic crust, may be related to a hotspot located above a mantle plume. Anomalous topography, gravity, crustal thickness, $\mathrm{S}$ wave and $\mathrm{P}$ wave velocities and geochemical signatures have been used as evidence for the existence of a plume in the Azores region (Schilling, 1975; Zhang and Tanimoto, 1992; Montagner and Ritsema, 2001; Montelli et al., 2004; Madureira et al., 2005; Silveira et al., 2006). Asimow et al. (2004) 
proposed an alternative model (the "wet spot" model) in which the so-called hotspot of the Azores region may be explained by a melting anomaly without a mantle temperature anomaly. This anomaly may be explained by a high degree of melting due to the presence of water in the mantle material. They used this model to justify the major element, trace element, isotopic, and crustal thickness relations observed along the Mid-Atlantic Ridge in the vicinity of the Azores platform. However, Anderson (2005) gave to the Azores very high plate scores (7) relative to plume scores (2): he pointed out that low velocities do not necessarily represent hot mantle, because chemistry, mineralogy, volatiles, anelasticity and anisotropy can also cause low-velocity zones and thinning of the transition zone. Mantle plumes are the focus of an intense debate and the controversy concerning their origin continues (Anderson, 2005).

The details of the Azores triple junction, including its exact geometry and the associated deformation, are poorly understood. While the boundary between the North American and the Eurasian and African plates is well established by the Mid-Atlantic Ridge, the location and nature of the eastern part of the Azores triple junction is still controversial (e.g. Madeira and Ribeiro, 1980; Luis, 1996; Lourenço et al., 1998; Miranda et al., 1998; Madeira, 1998). Classic kinematic plate motion models, such as the Nuvel-1A, predict, in the region of
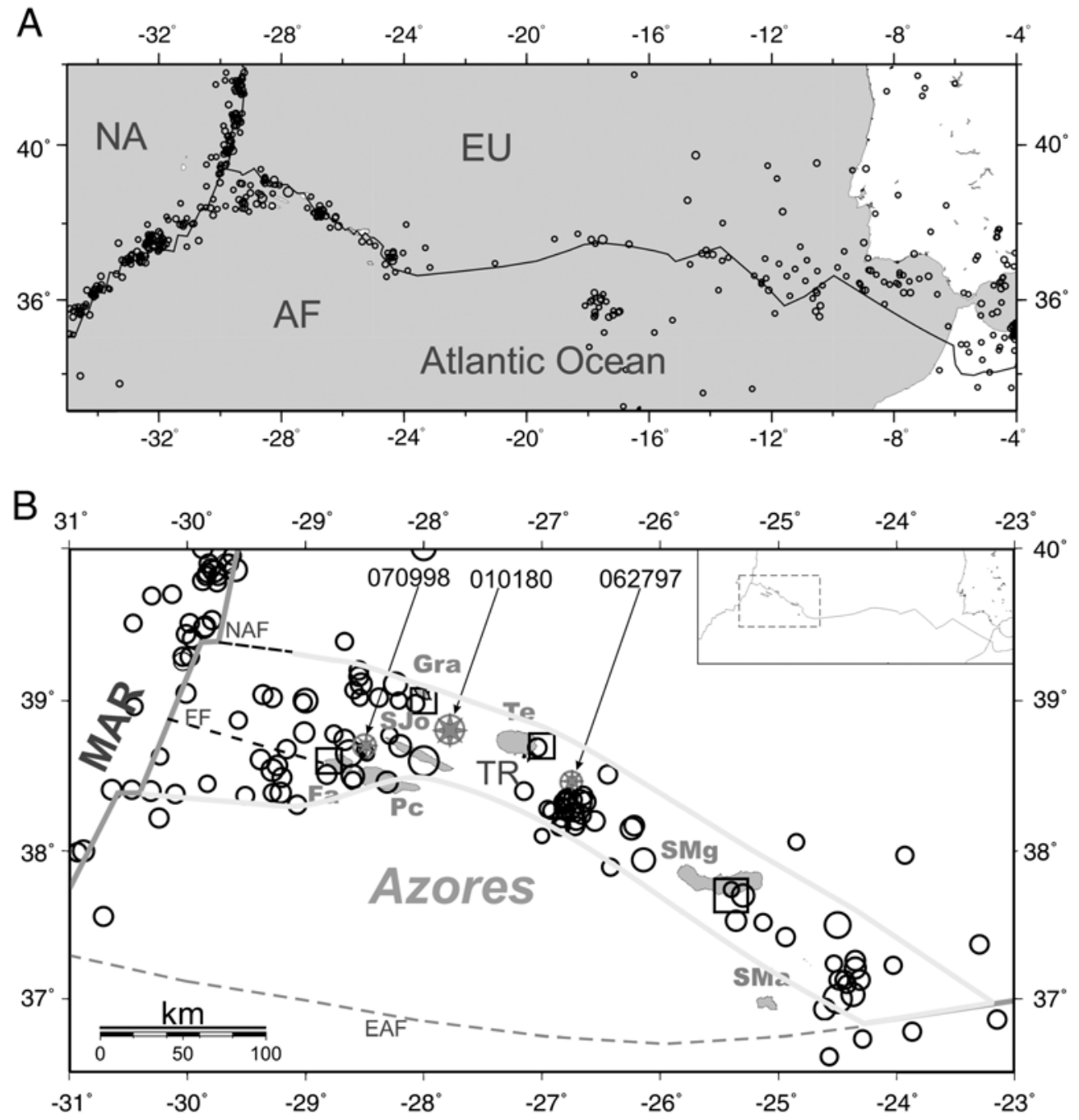

Fig. 2. (A). Seismicity of the Azores-Gibraltar region for the period 1973-2004 for magnitude $M \geq 4.0$ (NEIC Data File). (B). Details of instrumental (circles) and historical (squares) seismicity for the Azores region. The island names are Fa=Faial, Pc $=$ Pico, SJo=San Jorge, Gra $=$ Graciosa, $\mathrm{Te}=$ Terceira, $\mathrm{SMg}=$ San Miguel, SMa=Santa María. MAR, TR, NAF, FF, and EAF are as in Fig. 1. Grey stars show the epicentres of the three earthquakes studied. 
the Mid-Atlantic Ridge, relative motions between NA and $\mathrm{AF}$ of $2.3 \mathrm{~cm} / \mathrm{yr}$ in the north and $2.1 \mathrm{~cm} / \mathrm{yr}$ in the south (DeMets et al., 1994). Luis et al. (1994) proposed a model in which the relative plate motion at the MidAtlantic Ridge in the Azores region decreased from $4 \mathrm{~cm} / \mathrm{yr}$ to $1.4 \mathrm{~cm} / \mathrm{yr}$ in the interval from 10 to $3.85 \mathrm{Ma}$, and then reached a value of $2.5 \mathrm{~cm} / \mathrm{yr}$. The Nuvel-1A predicts a value of $4.5 \mathrm{~mm} / \mathrm{yr}$ and for the Terceira Ridge and recently, from Global Positioning System measurements (TANGO network), Fernandes et al. (2002) and Fernandes (2004) obtained a value of $4.2 \mathrm{~mm} / \mathrm{yr}$ in the vicinity of the central and eastern islands of the Azores.

Different explanations have been proposed for the origin of the Terceira Ridge. For some authors, it corresponds to an extensional zone normal to the MidAtlantic Ridge (Krause and Watkins, 1970; Udías, 1980; Buforn et al., 1988), or an oblique extension (McKenzie, 1972; Searle, 1980). Madeira and Ribeiro (1980) proposed a leaky transform model. Lourenço et al. (1998) proposed a diffuse boundary that is acting simultaneously as an ultra-slow spreading centre and as a transfer zone between the Mid-Atlantic Ridge and the dextral Gloria Fault, as it accommodates the differential shear motion between the Eurasian and African plates. Recently, Vogt and Jung (2004) suggested that the Azores axis, with a length of $550 \mathrm{~km}$, was the slowest spreading organized accreting plate boundary in the world, with a typical mixture of faulting mechanisms. Understanding the dynamics of the Azores triple junction is difficult because the very slow seafloor spreading rates at the Terceira Ridge $(<1 \mathrm{~cm} / \mathrm{yr})$. Nevertheless, the high level of seismicity along the Mid-Atlantic Ridge and the Terceira Ridge (Fig. 2A) is strongly associated with the seafloor spreading origin of the northeastward motion of the Eurasian plate with respect to the African plate (Buforn et al., 1988) (Fig. 2A). This was also supported by Fernandes (2004), who proposed an elastic model with two possible locations of the Azores triple junction: along the extension of the Terceira Ridge at the latitude of Graciosa Island or on the Faial fracture zone at the latitude of Faial Island (Fig. 2B).

The seismicity of the Azores region is associated with the boundary between the Eurasian, African and American plates. In general, the seismicity is of moderate magnitude and of shallow depth $(h<30 \mathrm{~km})$. Since 1920 only two earthquakes have had $M_{\mathrm{s}} \sim 7$, one on 8 May 1939, with its epicentre east of Santa María Island, and the other on 1 January 1980, with its epicentre between Terceira and Graciosa Islands. Most seismic activity is located on the Mid-Atlantic Ridge, a second zone with important seismic activity is located on NE-SW direction from the Ridge to Graciosa island
Table 1

Historical and instrumental epicentres reported in the area studied, based on Nunes and Ribeiro (2001)

\begin{tabular}{llllll}
\hline $\begin{array}{l}\text { Date } \\
\text { (dd/mm/yyyy) }\end{array}$ & Latitude & Longitude & $I_{\mathrm{o}}(\mathrm{MM})$ & Magnitude & Location \\
\hline $22 / 10 / 1522$ & $37.7^{\circ} \mathrm{N}$ & $25.4^{\circ} \mathrm{W}$ & $\mathrm{X}$ & - & S. Miguel \\
$24 / 05 / 1614$ & - & - & IX & - & Terceira \\
$09 / 07 / 1757$ & $38.6^{\circ} \mathrm{N}$ & $28.0^{\circ} \mathrm{W}$ & $\mathrm{XI} ?$ & - & S. Jorge \\
$21 / 01 / 1837$ & - & - & IX? & - & Graciosa \\
$15 / 06 / 1841$ & - & - & IX & - & Terceira \\
$31 / 08 / 1926$ & $38.5^{\circ} \mathrm{N}$ & $28.6^{\circ} \mathrm{W}$ & X & - & Faial \\
$08 / 05 / 1939$ & $37.0^{\circ} \mathrm{N}$ & $24.5^{\circ} \mathrm{W}$ & VII & $7.0-7.1$ & S. María \\
$26 / 06 / 1952$ & $37.7^{\circ} \mathrm{N}$ & $25.3^{\circ} \mathrm{W}$ & VII & - & S. Miguel \\
$26 / 06 / 1952$ & $38.7^{\circ} \mathrm{N}$ & $28.2^{\circ} \mathrm{W}$ & VIII & $5.5 \mathrm{mb}$ & S. Miguel \\
$13 / 05 / 1958$ & $38.6^{\circ} \mathrm{N}$ & $28.8^{\circ} \mathrm{W}$ & VIII/IX & - & Faial \\
$21 / 02 / 1964$ & $38.7^{\circ} \mathrm{N}$ & $28.2^{\circ} \mathrm{W}$ & VIII & $5.5 \mathrm{mb}$ & S. Jorge \\
$01 / 01 / 1980$ & $38.8^{\circ} \mathrm{N}$ & $27.8^{\circ} \mathrm{W}$ & VIII/IX & $7.2 \mathrm{Ms}$ & Terceira \\
$09 / 07 / 1998$ & $38.7^{\circ} \mathrm{N}$ & $28: 5^{\circ} \mathrm{W}$ & VIII/IX & $6.2 \mathrm{Mw}$ & Faial \\
\hline
\end{tabular}

$I_{\mathrm{o}}=$ maximum intensity

through Pico and Faial islands continuing into the Terceira Ridge (Fig. 2B), while the East Azores fracture zone is practically inactive. From historical seismicity, we know that large shocks have occurred in the Azores with maximum intensities of X (modified Mercalli MM) (Nunes and Ribeiro, 2001). In Table 1 and Fig. 2B, historical earthquakes with a maximum intensity of VII or larger, and earthquakes for the period 1973-2004 (National Earthquake Information Center Data File NEIC) with magnitudes greater than 4.0 are shown. From Fig. 2B, we observe that the historical and instrumental seismicities follow the same trend as the islands: approximately ENE from the Mid-Atlantic Ridge to Terceira Island (where the 1980 and 1998 shocks were located) and SE from Terceira Island to San Miguel Island (the 1997 earthquake was located SE of Terceira Island). Seismicity stops at $24^{\circ} \mathrm{W}$ where the Terceira Ridge joins with the Gloria Fault, which is considered seismically inactive (Fig. 2A).

Distribution of the aftershocks of the 1 January 1980 earthquake recorded at the telemetric seismic network installed on Terceira, S. Jorge, Graciosa and Pico Islands showed a $\mathrm{N} 150^{\circ} \mathrm{E}$ trend; this agrees with one of the fault planes estimated for the main shock (Hirn et al., 1980, Buforn et al., 1988; Grimison and Chen, 1988). An ocean bottom seismometer survey was carried out in the region in 1992. This showed a concentration of hypocentres along the islands themselves, with maximum depth of $15 \mathrm{~km}$ (Miranda et al., 1998). Finally, after the occurrence of the 1998 earthquake, a temporary seismic network was installed on the Faial, Pico and S. Jorge Islands. More than 1200 aftershocks were recorded, showing NNW-SSE to ENE-WSW alignments (Vales et al., 2001). 
Table 2

Velocity models used in the body-wave inversion for the 1980/1997 and 1998 events

\begin{tabular}{lll}
\hline Depth $(\mathrm{km})$ & Vp $(1980 / 1997)(\mathrm{km} / \mathrm{s})$ & Vp $(1998)(\mathrm{km} / \mathrm{s})$ \\
\hline 2.5 & 4.0 & 4.1 \\
5.0 & 5.9 & 5.9 \\
11.0 & 6.1 & 6.2 \\
14.0 & 7.3 & 7.3 \\
17.0 & 7.5 & 7.5 \\
20.0 & 8.2 & 8.3 \\
\hline
\end{tabular}

$\mathrm{Vp}=$ Velocity of $\mathrm{P}$ wave.

After the occurrence of 1980 earthquake the seismic activity on the region was low till the occurrence of two earthquakes on 1997 and 1998. The purpose of this paper is to study the seismic sources of the 1980, 1997 and 1998 Azores earthquakes, using all available seismological data, and to interpret the results obtained in the general seismotectonic context. We have used the focal mechanisms of the three earthquakes we studied, together with those obtained by other authors, in order to obtain a seismotectonic model for the Azores region. We have used observations of seismicity and focal mechanisms to examine the various characteristics of the Azores region. From the seismicity and focal mechanisms of events of shallow depth, we have deduced two different types of behaviour of the plate boundary from the Mid-Atlantic Ridge in the west to the western end of the Gloria Fault. In order to quantify the characteristics of the seismicity in these two zones, we have estimated the horizontal components normal to the Terceira Ridge of the average rate of the seismic slip for these two zones.

\section{Methodology and data}

Focal mechanisms of the 1980, 1997 and 1998 earthquakes have been studied using different methodologies. A preliminary fault plane solution has been obtained from first motion of $\mathrm{P}$ wave (Brillinger et al., 1980; Udías and Buforn, 1988). From body-wave inversion depth, scalar seismic moment, fault plane orientation and moment rate have been obtained. In order to avoid problems with the upper mantle wave triplications and diffractions by the mantle-core boundary, we retrieved broadband data recorded only at the teleseismic distances $\left(30^{\circ}<\Delta<90^{\circ}\right)$. For the 1980 event, we used records of the GDSN digital network. For the 1997 and 1998 events, we used data from the Incorporated Research Institutions for Seismology (IRIS) and GEOFOrschungsNetz (GEOFON) networks. We calculated ground motion from the seismograms, band pass filtered it and sampled it with intervals of $1 \mathrm{~s}$ for the 1980 and $0.1 \mathrm{~s}$ for the 1997 and 1998 earthquakes. The time windows we used were 60,15 and $20 \mathrm{~s}$, respectively. We used the waveform inversion method of Kikuchi and Kanamori (1991) and, to generate the Green functions, we used a crustal model (Table 2) derived from local studies in the region (Hirn et al., 1980; Vales et al., 2001). The use of specific crustal models for the studied regions with small differences on $\mathrm{P}$ wave velocity may permit a best constraint between the synthetic and observed data. In order to reduce the number of parameters to be estimated, using the algorithm of Brillinger et al. (1980), we first estimated the fault plane solution from the first motions of P waves (Fig. 3).

We used Rayleigh waves recorded on the broadband vertical component channel (LHZ) to estimate the directivity function for the 1998 and 1980 seismic events. Unfortunately the data are insufficient to estimate the directivity for 1997 earthquake by this method. The window we used was about $250 \mathrm{~s}$ and our frequency range was from 0.01 to $0.2 \mathrm{~Hz}$. Rupture velocity (v), direction and dimensions obtained from body-wave inversion were tested using the directivity function of the Rayleigh waves. This function, defined by Ben-Menahem (1961) for stations located at opposite azimuth from the source, was generalized for stations separated by an

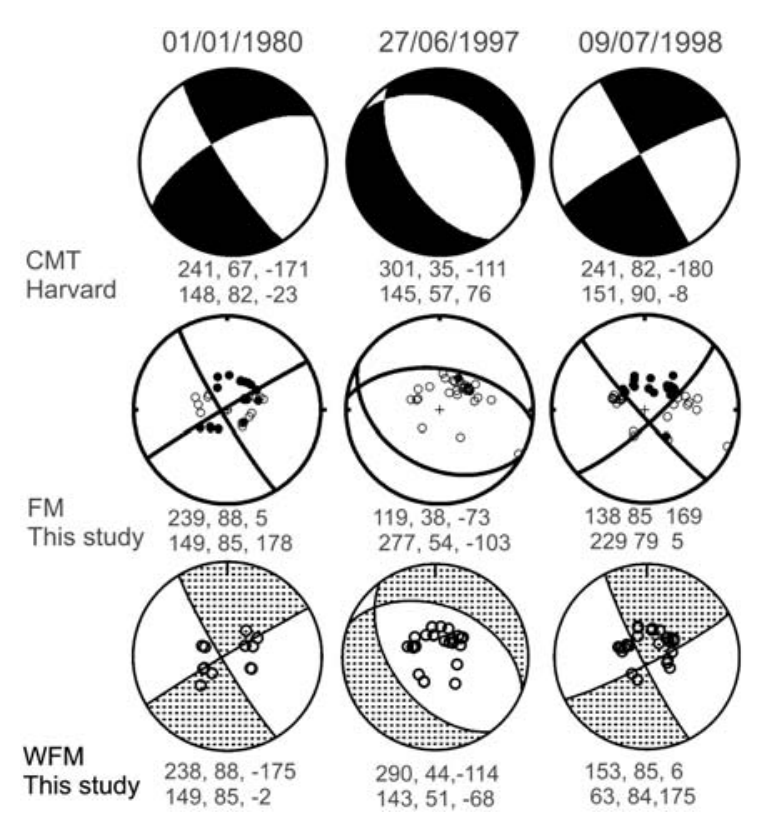

Fig. 3. Focal mechanisms for the 1980, 1997 and 1998 earthquakes found in this study and by other authors. CMT indicates centroidmoment tensor solutions of Harvard University; FM indicates first motion solutions obtained in this study; black circles correspond to compression and open circles to dilatation. WFM indicates focal mechanisms determined from waveform inversion in this study. The numbers below each focal mechanism are strike, dip and slip, respectively, for the first (upper line) and second (lower line) planes. 
angle $\alpha$ (Udías, 1971). For a vertical strike-slip fault and two stations at the same epicentral distance, the first one with azimuth $\theta$ and the second one with azimuth $\theta+\alpha$, the solution has a series of maxima and minima which are a function of the fault length, rupture velocity and phase velocity of the Rayleigh waves. The first low frequency maximum or minimum is used.

If we know the frequency value for this maximum or minimum, the fault length $L$ may be estimated assuming a value for the rupture velocity, or vice versa. However, an interrelation exists between $L$ and $v$ values, because different pairs of values may satisfy this condition. From the directivity function, we can deduce the fault plane and the rupture direction (Udías, 1971; Pro, 2002). In this way we can reduce the number of parameters in the body-wave inversion.

We also estimated scalar seismic moment $\left(M_{\mathrm{o}}\right)$ and source dimensions from spectral analysis of all available

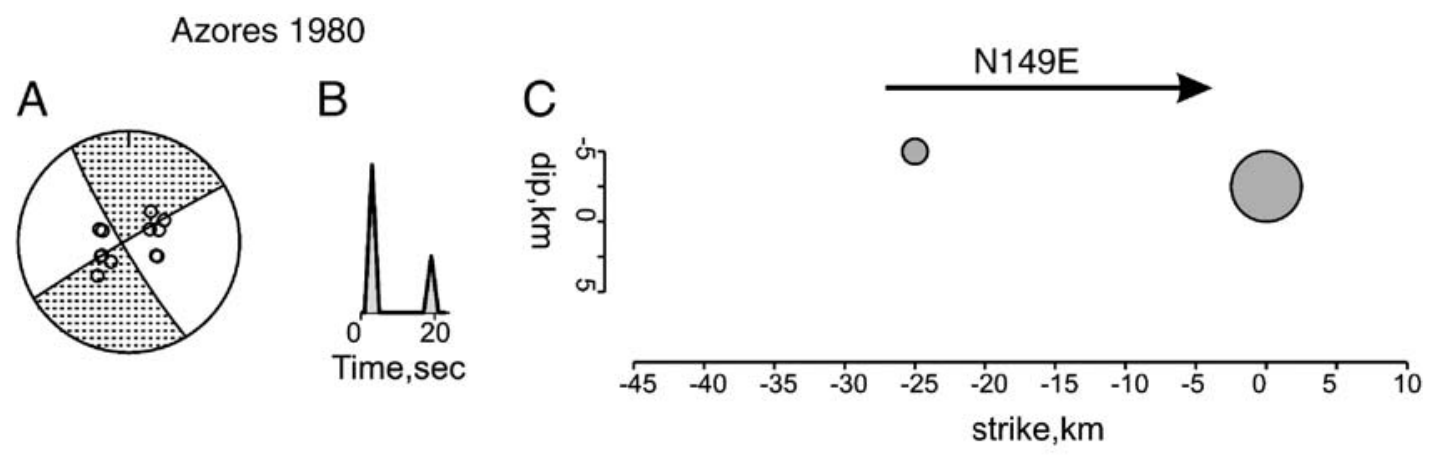

D
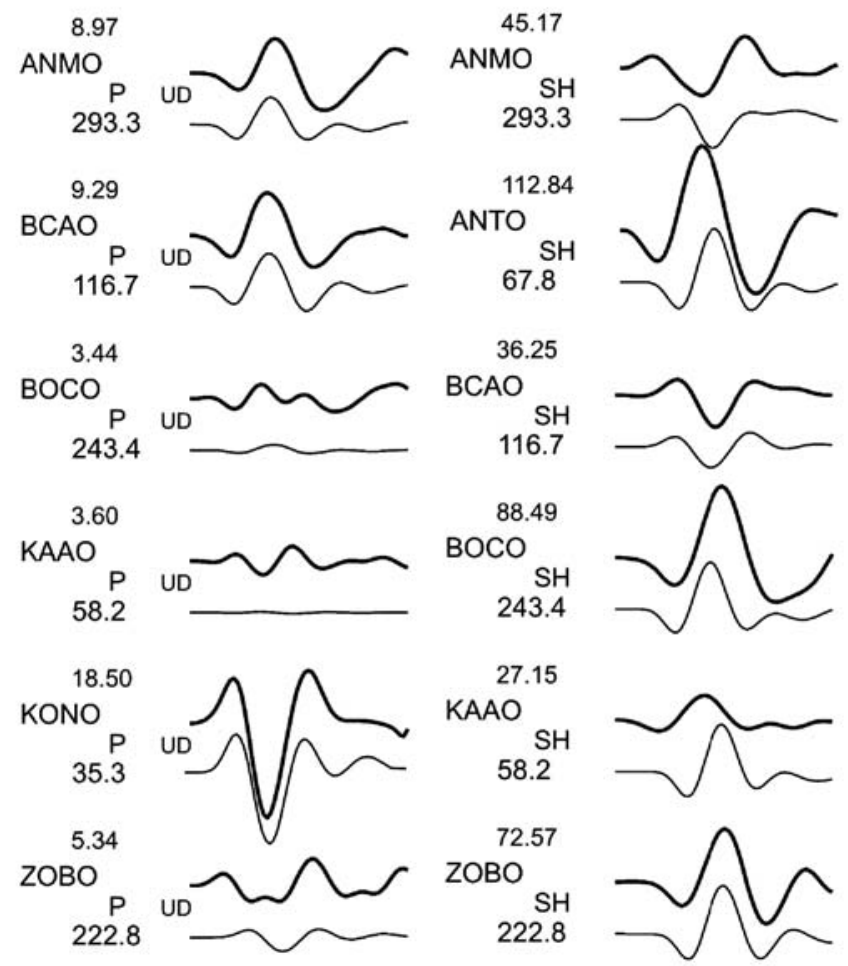

36.25
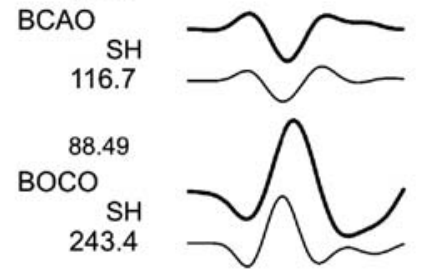

KAAO

58.2

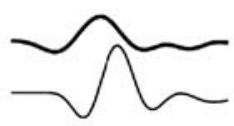

72.57

ZOBO

222.8

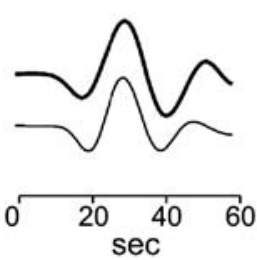

Fig. 4. A. Focal mechanism obtained from body-wave inversion for the 1 January 1980 earthquake, $M_{\mathrm{w}}=6.8$. B. Sequence of the two sub-events (source time function) with the same mechanism. C. Location of sub-events on the fault plane; symbols are proportional to the moment rate. D. Comparison between the observed (upper trace) and the synthetic (lower trace) waveforms (ground velocity). The number above the station code is the peak-to-trough value of the observed record in micrometers/s; the numbers below the station code are the station azimuth; UP, vertical component of $\mathrm{P}$ wave; and $\mathrm{SH}$, transverse component of $\mathrm{S}$ wave. 
digital seismograms for the three studied events. We windowed, detrended and deconvolved from the instrumental response the $\mathrm{P}$ and $\mathrm{SH}$ waves to obtain the amplitude spectra. The $M_{\mathrm{o}}$ and source dimensions obtained from spectral analysis are checked with these values obtained from body-wave inversion.

\section{The 1 January 1980 earthquake, $M_{\mathrm{w}}=6.8$}

The epicentre of this shock was located between Terceira and San Jorge Islands (Fig. 2B). Hypocentral coordinates for this shock were (NEIC) $38.81^{\circ} \mathrm{N}$, $27.78^{\circ} \mathrm{W}, H=10 \mathrm{~km}$, with an origin time of $16: 42: 40.0$ and $M_{\mathrm{s}}=6.7, M_{\mathrm{W}}=6.8$.

The shock reached maximum intensity VIII-IX (MM) at "Doze Ribeiras" (Terceira Island), 61 people were killed and 400 injured, a large part of the old city of Angra do Heroismo (Terceira Island), was destroyed and buildings on Terceira, San Jorge and Graciosa Islands were severely damaged (Machado and Silveira, 1982; Moreira, 1985). The shock was followed by more than 400 aftershocks, which were mainly distributed in a narrow band in a $\mathrm{N} 150^{\circ} \mathrm{E}$ direction (Hirn et al., 1980). The focal mechanism of the main shock has been the object of several studies, using first motion of $\mathrm{P}$ waves (Buforn et al., 1983; Nakanishi and Kanamori, 1984; Moreira, 1985; Buforn et al., 1988). Grimison and Chen (1988), using WWSSN long period records, obtained the focal mechanism from body-wave modelling. Hirn et al. (1980), using polarities recorded by a temporary network installed after the occurrence of the main shock, obtained a composite solution for the aftershocks.

To avoid errors introduced by the digitization of analogical records, we used only digital data. At the time of occurrence of this shock, only 12 GDSN digital records were available. In the inversion process, we used the solution obtained from $\mathrm{P}$ wave polarities ( $\operatorname{strike}=149^{\circ}, \operatorname{dip}=85^{\circ}$ ) as a preliminary fault plane orientation (Fig. 3). We modelled the source process as a sequence of two sub-events with the same mechanism. For the sub-event location, we took 20 grid points along a horizontal line at equal spaces of $5 \mathrm{~km}$. We assumed, as the initial break, the hypocentre given by NEIC, and for the synthetic Green functions, the lithospheric model given in Table 2. The initial depth was $7 \mathrm{~km}$; we used five grid points in a nearly vertical plane $\left(\mathrm{dip}=85^{\circ}\right)$ with an equal spacing of $2.5 \mathrm{~km}$. These values define a grid of $100 \mathrm{~km} \times 10 \mathrm{~km}$, with cells of $5 \mathrm{~km} \times 2.5 \mathrm{~km}$ and rupture velocity of $1.5 \mathrm{~km} / \mathrm{s}$. The data set consisted of six $\mathrm{P}$ and six $\mathrm{SH}$ waves and a window of $60 \mathrm{~s}$.

The results show two sub-events with a left-lateral strike-slip mechanism, with more energy released by the
Table 3

\begin{tabular}{lcccc}
\hline Stations & $\Theta\left({ }^{\circ}\right)$ & $\alpha\left(^{\circ}\right)$ & $L(\mathrm{~km})$ & $v(\mathrm{~km} / \mathrm{s})$ \\
\hline $\begin{array}{l}\text { a. Pairs of seismic stations } \\
\text { event }\end{array}$ & & & & \\
ANMO/BCAO & 218 & 176 & 18 & 1.5 \\
ZOBO/KONO & 288 & 186 & 30 & 1.8 \\
ANMO/KONO & 218 & 257 & 17 & 1.5 \\
& & & & \\
b. Pairs of seismic stations & used in the directivity study of the 1998 \\
$\quad$ event & & & & \\
KOG/PUL & 297 & 179 & 22 & 1.4 \\
WVT/KMBO & 230 & 180 & 30 & 1.4 \\
WCI/KMBO & 228 & 182 & 40 & 1.5 \\
LTX/KMBO & 231 & 179 & 35 & 1.5 \\
WCI/KOG & 228 & 69 & 40 & 1.5 \\
\hline
\end{tabular}

first one (Fig. 4). Considering the NNW-SSE plane as the fault plane, the second sub-event is located $25 \mathrm{~km}$ NNE of the first sub-event, at a shallow depth $(5 \mathrm{~km})$ and delayed $12 \mathrm{~s}$ from the first one. This result may be interpreted as a predominant propagation of the rupture SSE. The strike, dip and rake of the solution are $149^{\circ}$, $85^{\circ}$ and $-2^{\circ}$, respectively. Comparison between the observed and synthetic waveforms indicates a fairly good match at most stations, with the exception of $\mathrm{P}$ waves at KAAO (azimuth $58^{\circ}$ ) and $\mathrm{ZOBO}$ stations (azimuth $223^{\circ}$ ). The total seismic moment is $1.9 \times 10^{19} \mathrm{Nm}\left((1.4+0.5) \times 10^{19} \mathrm{Nm}\right)$, which, using the Kanamori (1978) equation, gives $M_{\mathrm{w}}=6.8$. The source time function (STF) is formed by two triangles of $4 \mathrm{~s}$ time duration, the second one delayed $12 \mathrm{~s}$. The existence of second sub-event (about 25\% of the total seismic moment) could justify the high intensities felt in the oriental part of the Graciosa Island (maximum intensity of VII according to Machado and Silveira, 1982).

From spectral analysis of five $\mathrm{P}$ waves recorded at teleseismic distances, $M_{\mathrm{o}}$ is $(2.8 \pm 3) \times 10^{19} \mathrm{Nm}$ $\left(M_{\mathrm{w}}=6.9\right)$, slightly higher than that obtained from the waveform analysis, and the fault length is $50 \mathrm{~km}$ (Table 4). If we assume a rectangular fault of width $10 \mathrm{~km}$, the stress drop is $0.5 \mathrm{MPa}$.

To test the solution obtained, we have used three pairs of stations to estimate rupture velocity and direction (Table 3 and Fig. 5A) from the directivity function of LR waves. Using $149^{\circ}$ as the rupture azimuth, and the propagation of the rupture to SSE, we found, from the directivity function, a rupture velocity of $1.5-1.8 \mathrm{~km} / \mathrm{s}$ and a length of fracture of about $17-$ $30 \mathrm{~km}$ (Table 3).

Comparison of our solution with the results of other authors shows a good agreement on the fault plane orientation. Thus, Hirn et al. (1980) and Buforn et al. (1988) obtained, from polarities, a pure left-lateral 
A
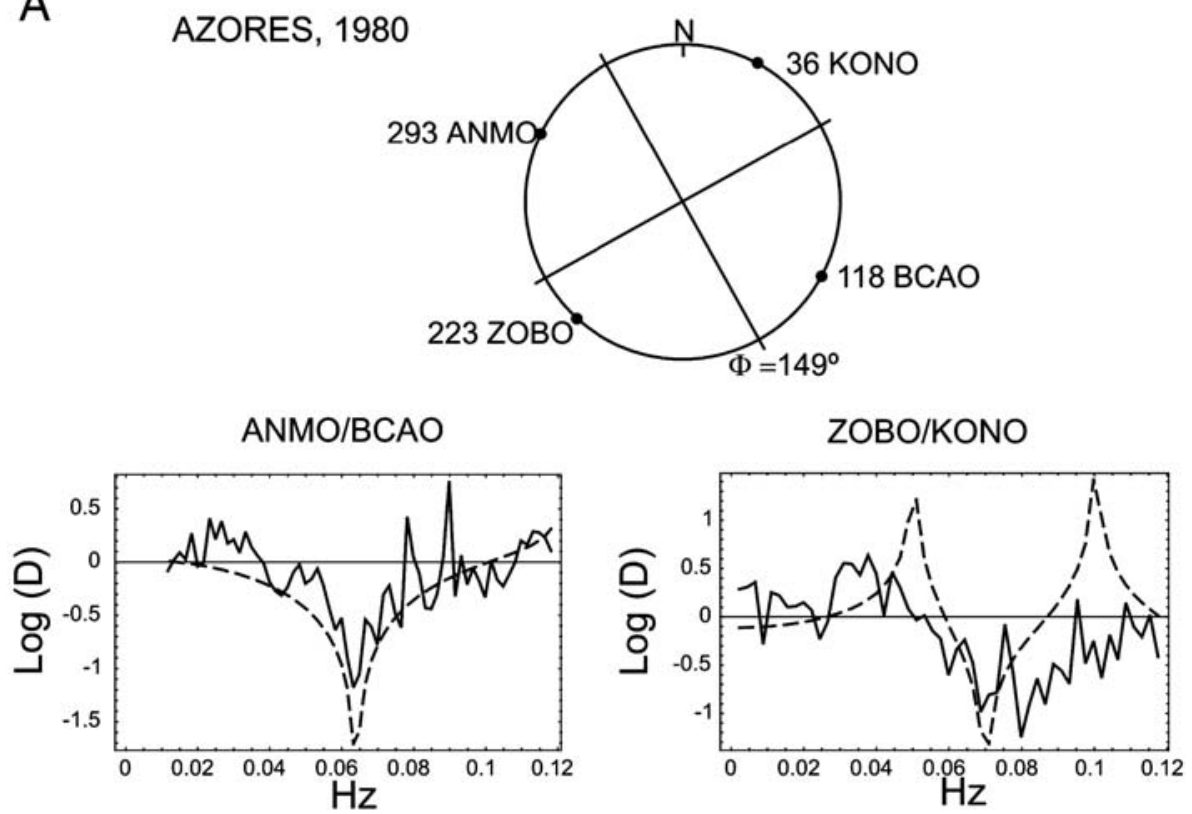

B

AZORES, 1998
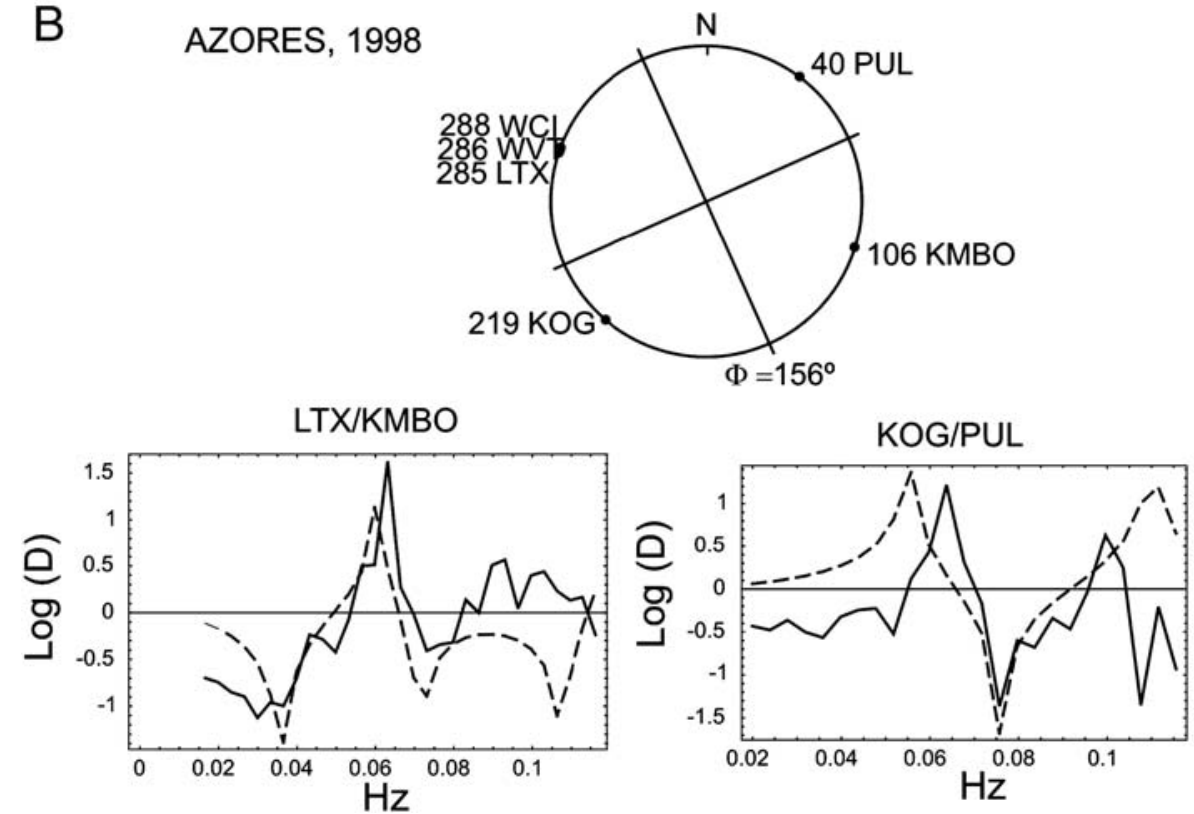

Fig. 5. Directivity functions indicated by D, for the 1980 (A) and 1998 (B) earthquakes. Top: azimuthal distribution of stations used, numbers corresponding to the azimuth and fault plane used as rupture plane. Bottom: theoretical (dashed) and observed (continuous line) directivity function, $(\log \mathrm{D})$, for a pair of stations. $A=$ difference of azimuth, $\Phi=$ trend of rupture, $L=$ rupture length, $v=$ rupture velocity obtained from the directivity function.

strike-slip motion with a vertical plane trending between $149^{\circ}$ and $154^{\circ}$. Grimison and Chen (1988) obtained from waveform modelling, a similar solution with left-lateral strike-slip. Grimison and Chen obtained another solution using an extended source, with two sub-events, the first one with a pure strike-slip mechanism and the second one with a large component of a thrust fault. The first event was located at $12 \mathrm{~km}$ depth and the second one at $20 \mathrm{~km}$ depth; these depths do not appear to be realistic for an earthquake located in 

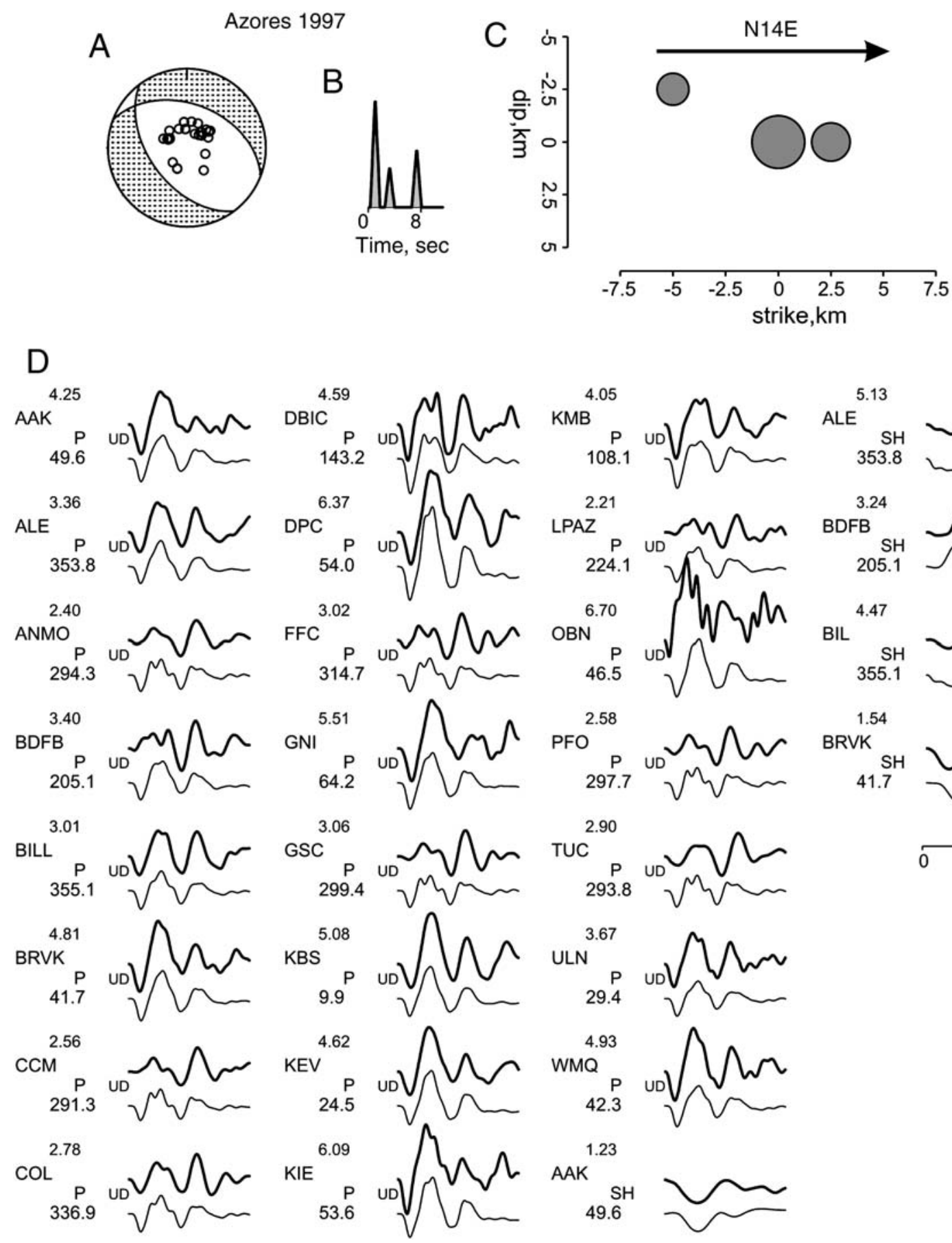

Fig. 6. A. Focal mechanism obtained from inversion of body-waves for the 27 June 1997 earthquake, $M_{\mathrm{w}}=5.9$. B. Sequence of the three sub-events (source time function) with the same mechanisms. C. Location of sub-events in the fault plane; symbols are proportional to the moment rate. D. Comparison between the observed (upper trace) and the synthetic (lower trace) waveforms (ground motion). The number above the station code is the peak-to-trough value of the observed record in micrometers, and the number below the station code is the station azimuth; UP vertical component of P wave; SH transverse component of S wave.

oceanic-type crust. Most of the aftershocks were located at less than $10 \mathrm{~km}$ depth (Hirn et al., 1980). The uniqueness of the solution is not easily determined because of the trade-off between various focal parameters, particularly between the depth and the STF. We know that the changes in the Green's function caused by 
an incorrect assumed depth can almost always be compensated by changes in the source function, producing the same seismogram (Christensen and Ruff, 1985; Bezzeghoud, 1987). Another difference between our study and that of Grimison and Chen is the data used. We used digital records, and Grimison and Chen used digitized analogical WWSSN long-period seismograms: they could have introduced some distortions between the original and digitized data. Comparison between our STF and those obtained by Grimison and Chen shows a shorter time duration for ours, and the second sub-event delayed $12 \mathrm{~s}$ in relation to the first. The value of $M_{\mathrm{o}}=3.8 \times 10^{19} \mathrm{Nm}$ obtained by Grimison and Chen is larger than the values obtained in this study $\left(1.9 \times 10^{19}\right.$ and $2.8 \times 10^{19} \mathrm{Nm}$ from inversion and spectral analysis, respectively).

\section{The 27 June 1997 earthquake, $M_{w}=\mathbf{5 . 9}$}

The second earthquake, 27 June 1997, occurred in the eastern part of the Azores Islands, between Terceira and San Miguel Islands, in a region with a high level of seismicity (Fig. 2B); it produced no damage. Hypocentral coordinates, according to NEIC, were $38.33^{\circ} \mathrm{N}, 26.68^{\circ} \mathrm{W}$, $H=10 \mathrm{~km}$, with an origin time of 04:39:52.72; $M_{\mathrm{s}}=5.4$, $M_{\mathrm{w}}=5.9$.

We estimated a fault plane solution from polarities of $37 \mathrm{P}$ waves. We used data from broadband stations recording at teleseismic distances (IRIS and GEOFON). We used the solution we obtained (Fig. 3) as a preliminary orientation for the body-wave inversion. Owing to the moderate magnitude of the earthquake, we observed no directivity effects. For this reason, we tested both planes in the inversion process. We obtained the best fit between observed and theoretical records for the plane with $143^{\circ}$ azimuth, $51^{\circ}$ dip and $-111^{\circ}$ rake. In the inversion we used a fault plane with dimensions of $25 \mathrm{~km} \times 12.5 \mathrm{~km}$, with a grid of $2.5 \mathrm{~km} \times 2.5 \mathrm{~km}$ and a rupture velocity of $1.5 \mathrm{~km} / \mathrm{s}$. We used a total of $23 \mathrm{P}$ and five $\mathrm{SH}$ waves (Fig. 6). In a window of $15 \mathrm{~s}$, we deconvolved the data from the instrumental response, filtered and finally resampled them to $0.1 \mathrm{~s}$. We estimated Green functions using the lithospheric model given in Table 2. Our results showed normal faulting with the fault plane oriented NW-SE (azimuth $=143^{\circ}$ ) and dipping $51^{\circ}$. The rupture process may be described as follows. The rupture started at $7 \mathrm{~km}$ depth with a time duration of $2.5 \mathrm{~s}$. At the second step it stopped and, after $1 \mathrm{~s}$, the rupture moved $2.5 \mathrm{~km}$ to the SE of its beginning with a time duration of $2.5 \mathrm{~s}$. It stopped again and it started again at $6.7 \mathrm{~s}$, at $5 \mathrm{~km}$ depth and $5 \mathrm{~km} \mathrm{NW}$ of its beginning. The total $M_{\mathrm{o}}$ was
Table 4

Values of seismic moment $\left(M_{\mathrm{o}}\right)$, corner frequency (fc), radius $(R)$ and area $(A)$ of the fault, Magnitude moment $\left(M_{\mathrm{w}}\right)$, stress drop $(\Delta \sigma)$ and average displacement $(u)$ obtained from the spectral analysis of the $\mathrm{P}$ waves

\begin{tabular}{|c|c|c|c|c|c|c|c|}
\hline Event & $\begin{array}{l}M_{\mathrm{o}} \\
(\mathrm{Nm})\end{array}$ & $\begin{array}{l}\mathrm{fc} \\
(\mathrm{Hz})\end{array}$ & $\begin{array}{l}R \\
(\mathrm{~km})\end{array}$ & $\begin{array}{l}A \\
\left(\mathrm{~km}^{2}\right)\end{array}$ & $M_{\mathrm{w}}$ & $\begin{array}{l}\Delta \sigma \\
(\mathrm{MPa})\end{array}$ & $\begin{array}{l}u \\
(\mathrm{~m})\end{array}$ \\
\hline $\begin{array}{c}01 / 01 / \\
1980\end{array}$ & $2.8 \times 10^{19}$ & 0.1 & 12.6 & $\begin{array}{l}500(L=50 \\
\mathrm{W}=10 \mathrm{~km})^{*}\end{array}$ & 6.9 & 0.5 & 1.7 \\
\hline $\begin{array}{c}27 / 06 / \\
1997\end{array}$ & $9.0 \times 10^{17}$ & 0.43 & 3,0 & 27 & 5.9 & 1.6 & 1.0 \\
\hline $\begin{array}{c}09 / 09 / \\
1998\end{array}$ & $2.3 \times 10^{18}$ & 0.34 & 3.7 & 43 & 6.2 & 2.0 & 1.6 \\
\hline
\end{tabular}

We consider the circular rupture model of Brune (1970) for the 1997 and 1998 events. For the stress drop of the 1980 event we used the expression of Kanamori and Anderson (1975).

* From Brune (1970) ratios considering a seismogenic thick layer of $10 \mathrm{~km}$.

$7.0 \times 10^{17} \mathrm{Nm}(3.1+1.8+2.1) \times 10^{17} \mathrm{Nm}\left(M_{\mathrm{w}}=5.8\right)$ with most energy released at the first step. From the spectra of $10 \mathrm{P}$ waves recorded at teleseismic distances, we obtained a scalar seismic moment of $9.0 \times 10^{17} \mathrm{Nm}$ $\left(M_{\mathrm{w}}=5.9\right)$ and, assuming a circular fault, a radius of $5 \mathrm{~km}$, the stress drop being $3.0 \mathrm{MPa}$ (Table 4). The scalar seismic moment and focal mechanism obtained in our study are in agreement with the solutions obtained by Harvard University (central-moment tensor CMT), US Geological Survey (USGS) and the Earthquake Research Institute (University of Tokyo - ERI).

\section{The 9 July 1998 earthquake, $M_{w}=6.0$}

The seismic event of 9 July 1998 had its epicentre $8 \mathrm{~km} \mathrm{NE}$ of Faial Island (Fig. 2A), where seismicity follows a NE-SW trend. The shock caused severe damage on Faial Island, where $I_{\mathrm{o}}=$ VIII $(\mathrm{MM})$ was reached, causing 8 deaths, 150 persons injured and 1500 homeless (Senos et al., 1998). Hypocentral coordinates according to NEIC are $38.65^{\circ} \mathrm{N}, 28.63^{\circ} \mathrm{W}, H=10 \mathrm{~km}$, with an origin time of 05:19:07:30; $M_{\mathrm{s}}=6.0, M_{\mathrm{w}}=6.0$.

The fault plane solution obtained from first motion of $P$ waves showed a focal mechanism of strike-slip motion with planes oriented NW-SE and NE-SW, directions similar to those of the 1980 event (Fig. 3). The vertical plane, with azimuth $=153^{\circ}$ and dip $=85^{\circ}$, was used in the inversion process of body-waves. We used a rectangular plane of $25 \mathrm{~km} \times 12.5 \mathrm{~km}$, with a grid of $2.5 \mathrm{~km} \times 2.5 \mathrm{~km}$, as a fault plane. We used, with a time window of $25 \mathrm{~s}, 17 \mathrm{P}$ and $10 \mathrm{SH}$ waves, deconvolved them from the instrument, integrated, filtered and resampled them at $0.1 \mathrm{~s}$; the rupture velocity was $1.5 \mathrm{~km} / \mathrm{s}$. 

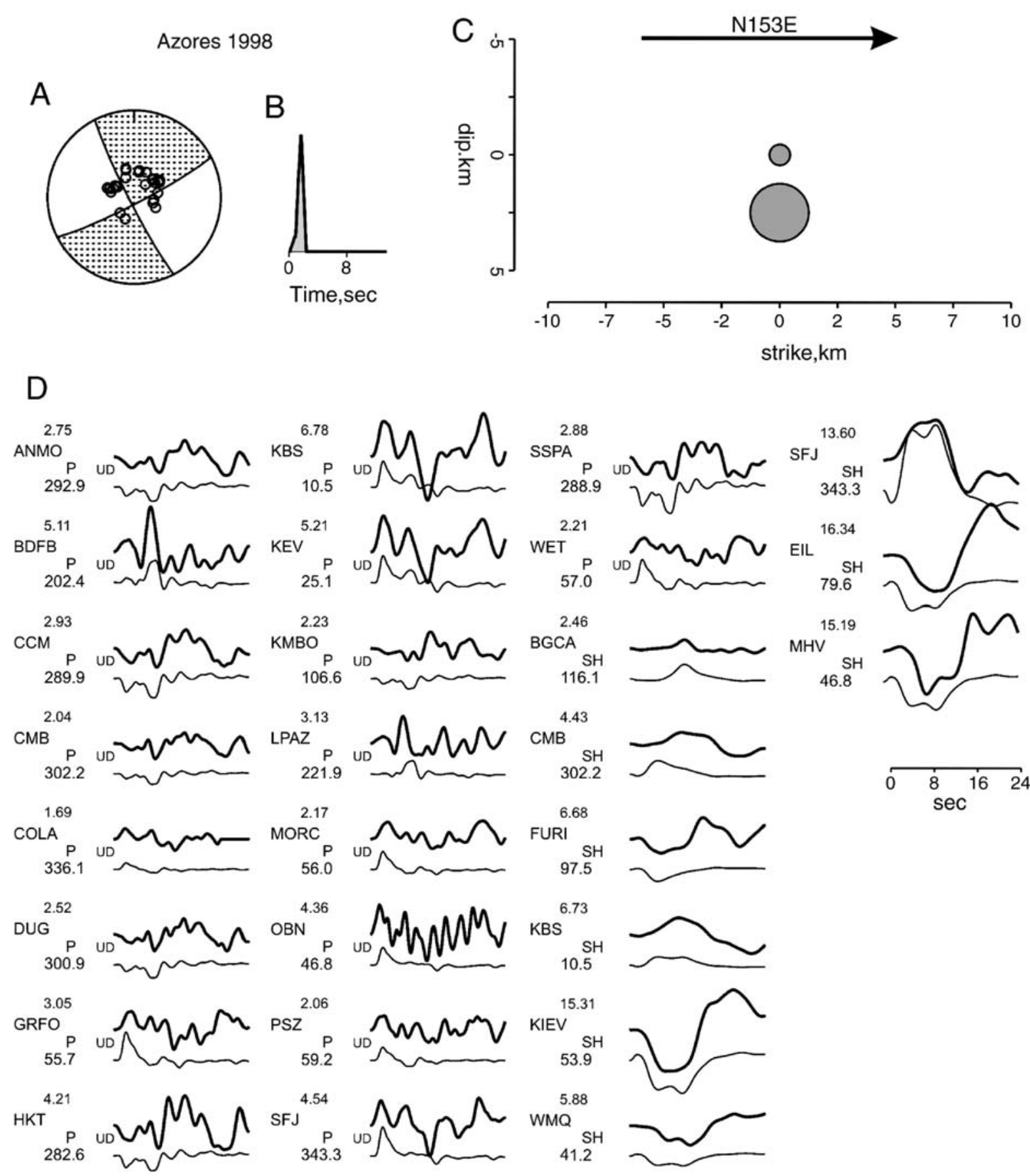

6.73
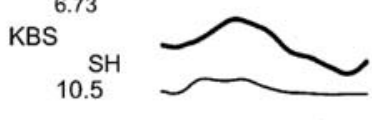

2.06
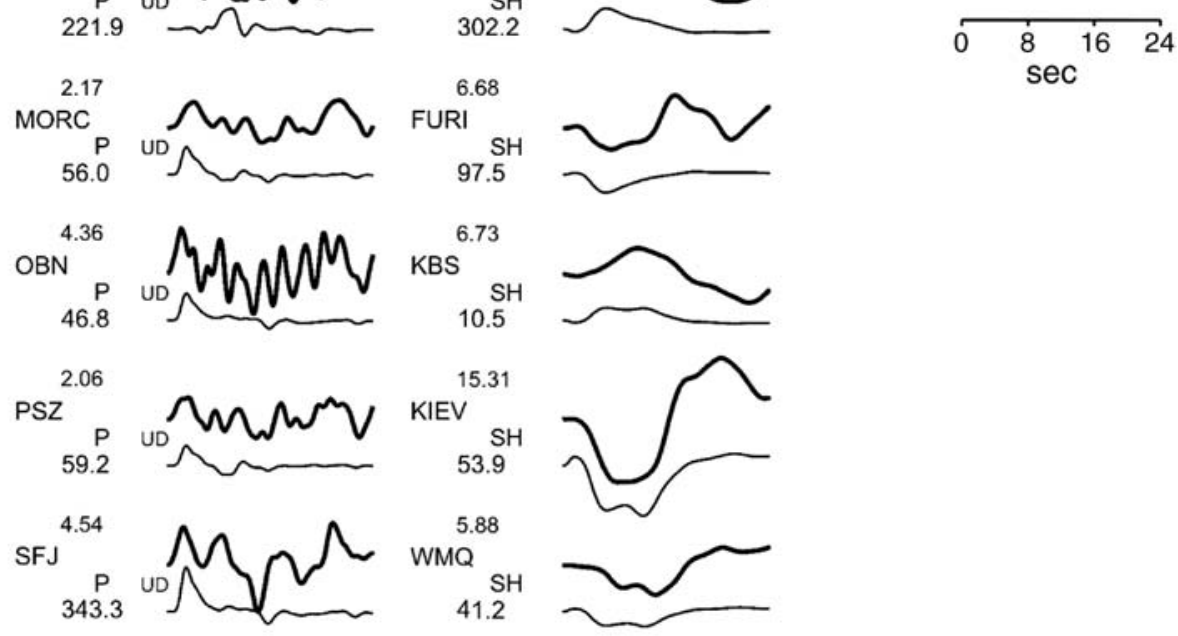

Fig. 7. A. Focal mechanism obtained from body-wave inversion for the 9 July 1998 earthquake, $M_{\mathrm{w}}=6.0$. B. Sequence of the two sub-events (source time function) with the same mechanisms. C. Location of sub-events on the fault plane; symbols are proportional to the moment rate. D. Comparison between the observed (upper trace) and the synthetic (lower trace) waveforms (ground motion). The number above the station code is the peak-totrough value of the observed record in micrometers, and the number below the station code is the station azimuth; UP vertical component of P wave; SH transverse component of S wave.

Our solution (dip $=85^{\circ}$ - Fig. 7) showed a rupture process similar to that of the 1980 earthquake, with two sub-events, and most energy released in the first event at
$8 \mathrm{~km}$ depth, with left-lateral strike-slip motion. We located the second sub-event at the same horizontal position as the first one, but at a shallower depth $(7 \mathrm{~km})$ 
and with less energy released. The source time function had a time duration of $2.5 \mathrm{~s}$. The scalar seismic moment was $1.4 \times 10^{18} \mathrm{Nm}(1.1+0.3) \times 10^{18} \mathrm{Nm}\left(M_{\mathrm{w}}=6.0\right)$. From a spectral analysis of nine $\mathrm{P}$ waves at teleseismic distances we estimated $M_{\mathrm{o}}=2.3 \times 10^{18} \mathrm{Nm}\left(M_{\mathrm{w}}=6.2\right)$, similar to those obtained from inversion, a fault plane area of $30 \mathrm{~km}^{2}$ and stress drop of $3 \mathrm{MPa}$ (Table 4).

In order to check which the fault plane was, we estimated the directivity function from LR waves using five pairs of stations (Table 3 and Fig. 5B). We found the plane with azimuth $=156^{\circ}$ as the fault plane, and a rupture velocity $=1.5 \mathrm{~km} / \mathrm{s}$, similar to that obtained for other shocks in this region (Udías, 1971; Pro, 2002).

\section{Discussion}

The results for the three earthquakes that we have studied from the inversion of $\mathrm{P}$ waves, the directivity function and spectral analysis may be summarized as follows. We have obtained strike-slip solutions for the 1980 and 1998 events, and normal faulting for the 1997 event. Teleseismic P wave inversion showed complex source time functions for the 1980 and 1997 earthquakes, formed by two and three sub-events, respectively, at very shallow depths $(7 \mathrm{~km})$, with scalar seismic moments of $1.9 \times 10^{19} \mathrm{Nm}$ and $7.0 \times 10^{17} \mathrm{Nm}$. The moment release of the 1998 earthquake was almost concentrated in a single event, with a shallow depth $(7.0 \mathrm{~km})$ and scalar seismic moment of $1.4 \times 10^{18} \mathrm{Nm}$. From spectral analysis of $\mathrm{P}$ waves recorded at teleseismic distances, we have obtained scalar seismic moments for the $1980\left(M_{\mathrm{o}}=2.8 \times 10^{19} \mathrm{Nm}\right), 1997$ $\left(M_{\mathrm{o}}=9.0 \times 10^{17} \mathrm{Nm}\right)$ and $1998\left(M_{\mathrm{o}}=2.3 \times 10^{18} \mathrm{Nm}\right)$ earthquakes slightly higher than those obtained from the waveform inversion. All events have a low static stress drop (between 0.5 and $2.0 \mathrm{MPa}$ ) and a very low rupture velocity $(1.5 \mathrm{~km} / \mathrm{s}$, which is approximately one-half that of shear wave velocity of the region).

If we compare values of scalar seismic moment that we have obtained in this study by wave form inversion and spectral analysis with the CMT values, a difference of a factor of two is found for 1980 earthquake $\left(M_{\mathrm{o}}=2.81 \times 10^{19} \mathrm{Nm}\right)$. For the 1997 $\left(M_{\mathrm{o}}=7.43 \times 10^{17} \mathrm{Nm}\right)$ and $1998\left(M_{\mathrm{o}}=1.98 \times 10^{18} \mathrm{Nm}\right)$ earthquakes, our scalar seismic moments are similar to the CMT values. However, the CMT method sometimes overestimates the scalar seismic moment (Bezzeghoud and Buforn, 1999). A factor of three difference in scalar seismic moment values compared with the CMT solution, that may be explained by the frequency

Table 5

Focal parameters of the Azores area used to plot the Frohlich diagram and the seismic moment tensor shown in Figs. 8, 9 and 10

\begin{tabular}{|c|c|c|c|c|c|c|c|c|c|c|c|c|c|c|}
\hline No. & Date $(\mathrm{d} / \mathrm{m} / \mathrm{yr})$ & Latitude $\left({ }^{\circ} \mathrm{N}\right)$ & Longitude $\left({ }^{\circ} \mathrm{E}\right)$ & Depth $(\mathrm{km})$ & $M$ & $M_{\mathrm{o}}\left(\times 10^{17} \mathrm{Nm}\right)$ & Strike & Dip & Rake & $P \Phi$ & $P \Theta$ & $T \Phi$ & $T \Theta$ & REF. \\
\hline 1 & 20/01/1993 & 38.39 & -29.34 & 15 & $5.4 \mathrm{w}$ & 1.20 & 132 & 33 & -59 & 151 & 67 & 20 & 16 & CMT \\
\hline 2 & $11 / 12 / 1973$ & 38.74 & -28.67 & 15 & $5.0 \mathrm{w}$ & 0.34 & 329 & 58 & -20 & 294 & 35 & 197 & 10 & BUF \\
\hline 3 & 09/07/1998 & 38.65 & -28.63 & 7 & $6.0 \mathrm{w}$ & 14 & 153 & 85 & 6 & 288 & 1 & 18 & 8 & This study \\
\hline 4 & 23/11/1973 & 38.46 & -28.31 & 15 & $5.1 \mathrm{~s}$ & 2.0 & 23 & 90 & -179 & 247 & 1 & 157 & 1 & BUF \\
\hline 5 & 01/01/1980 & 38.81 & -27.78 & 7 & $6.8 \mathrm{w}$ & 190 & 149 & 85 & -2 & 104 & 5 & 14 & 2 & This study \\
\hline 6 & 28/06/1997 & 38.41 & -26.64 & 15 & $5.1 \mathrm{w}$ & 0.58 & 335 & 44 & -87 & 1 & 88 & 243 & 1 & CMT \\
\hline 8 & $20 / 04 / 1968$ & 38.30 & -26.60 & 15 & $4.6 \mathrm{w}$ & 0.09 & 117 & 42 & 89 & 28 & 3 & 220 & 87 & BUF \\
\hline 7 & 06/09/1964 & 38.30 & -26.60 & 15 & $5.1 \mathrm{w}$ & 0.54 & 185 & 62 & 3 & 142 & 17 & 46 & 21 & BUF \\
\hline 9 & 27/06/1997 & 38.33 & -26.68 & 7 & $5.8 \mathrm{w}$ & 7.0 & 143 & 51 & -68 & 115 & 73 & 216 & 3 & This study \\
\hline 10 & $21 / 11 / 1988$ & 38.34 & -26.27 & 15 & $5.9 w$ & 7.10 & 345 & 29 & -37 & 348 & 55 & 217 & 25 & CMT \\
\hline 11 & 27/06/1997 & 38.26 & -26.16 & 15 & $5.2 \mathrm{w}$ & 0.62 & 284 & 27 & -147 & 102 & 54 & 236 & 27 & CMT \\
\hline 12 & $02 / 12 / 1981$ & 38.38 & -26.13 & 15 & $5.6 \mathrm{w}$ & 3.20 & 141 & 42 & -80 & 162 & 82 & 43 & 3 & CMT \\
\hline 13 & $21 / 01 / 1989$ & 37.92 & -25.92 & 15 & $5.7 \mathrm{w}$ & 3.40 & 131 & 41 & -87 & 195 & 85 & 39 & 5 & CMT \\
\hline 14 & $16 / 10 / 1988$ & 37.38 & -25.16 & 15 & $5.3 \mathrm{w}$ & 0.89 & 303 & 90 & 180 & 168 & 0 & 258 & 0 & CMT \\
\hline 15 & 05/07/1966 & 37.60 & -24.70 & 18 & $5.0 \mathrm{w}$ & 0.41 & 180 & 48 & 30 & 129 & 12 & 24 & 48 & BUF \\
\hline 16 & 04/07/1966 & 37.50 & -24.70 & 10 & $5.5 \mathrm{w}$ & 1.90 & 341 & 49 & -42 & 318 & 55 & 219 & 6 & BUF \\
\hline 17 & 08/05/1939 & 37.40 & -23.90 & 15 & $7.1 \mathrm{~s}$ & 199 & 41 & 35 & -154 & 234 & 49 & 355 & 24 & BUF \\
\hline 18 & 09/03/1996 & 37.13 & -23.85 & 15 & $5.7 \mathrm{w}$ & 3.80 & 319 & 28 & -106 & 85 & 71 & 241 & 18 & CMT \\
\hline 19 & 09/12/1991 & 37.22 & -23.61 & 15 & $5.2 \mathrm{w}$ & 0.82 & 330 & 45 & -90 & 180 & 90 & 240 & 0 & CMT \\
\hline 20 & 09/09/1984 & 36.93 & -24.60 & 12 & $5.3 \mathrm{w}$ & 0.95 & 178 & 37 & -79 & 221 & 79 & 81 & 8 & CMT \\
\hline 21 & 26/06/1989 & 39.11 & -28.32 & 15 & $5.8 \mathrm{w}$ & 5.40 & 105 & 32 & -110 & 248 & 72 & 29 & 14 & CMT \\
\hline 22 & $23 / 09 / 1989$ & 39.27 & -29.24 & 15 & $5.1 \mathrm{w}$ & 0.44 & 233 & 45 & -90 & 180 & 90 & 143 & 0 & CMT \\
\hline 23 & $01 / 08 / 2000$ & 38.79 & -29.01 & 15 & $5.1 \mathrm{w}$ & 0.51 & 97 & 62 & -170 & 316 & 26 & 53 & 13 & CMT \\
\hline 24 & $30 / 11 / 2002$ & 39.25 & -28.45 & 15 & $5.1 \mathrm{w}$ & 0.52 & 106 & 45 & -129 & 300 & 63 & 42 & 6 & CMT \\
\hline
\end{tabular}

$P_{\Phi}, T_{\Phi}=$ trend of pressure and tension axes; $P_{\theta}, T_{\theta}=90^{\circ}$ - plunge of pressure and tension axes; CMT=centroid-moment tensor $($ Harvard); BUF $=$ Buforn et al., 1988. For magnitude, w and s indicate, respectively, $M_{\mathrm{w}}$ and $M_{\mathrm{s}}$. 


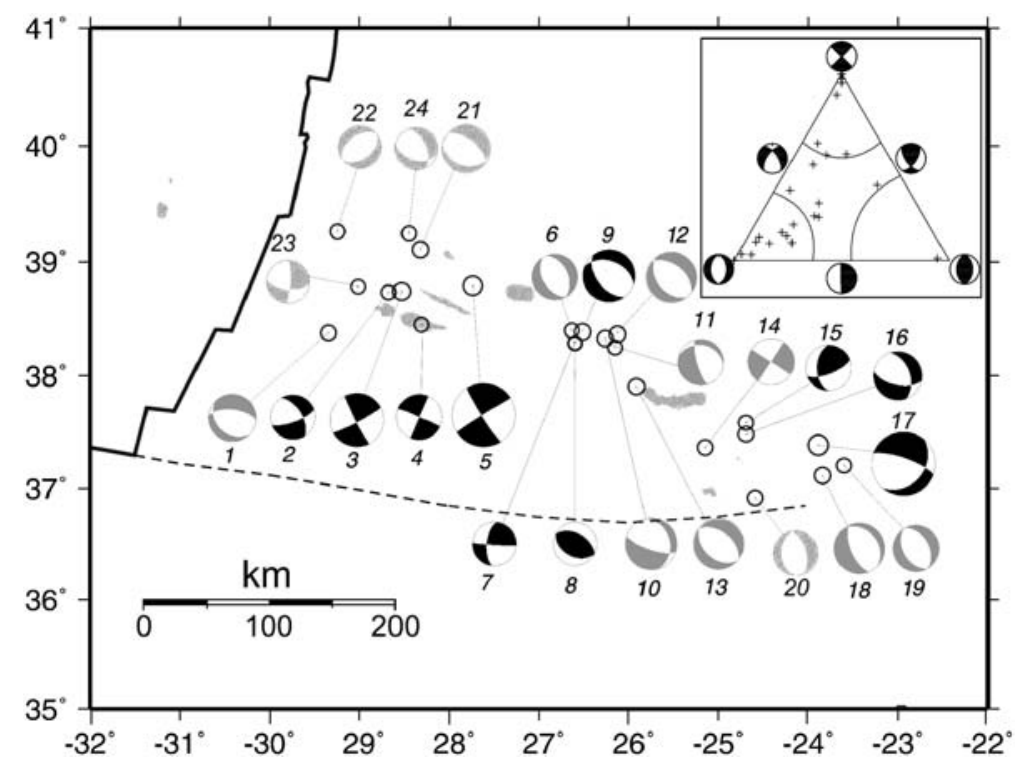

Fig. 8. Focal mechanisms for the Azores region. In black: solutions obtained from body-wave inversion and polarities by several authors. In grey: CMT solutions. Numbers correspond to Table 5. In the right top: the Frohlich diagram obtained from focal mechanism parameters of earthquakes listed in Table 5. Grey line represent the limit of the seismic active zone.

content of waveforms, has been obtained by some authors (Tanioka and Ruff, 1997).

The precision of the hypocentral determination given by the inversion of $\mathrm{P}$ waves in the Azores region is $\pm 2.5 \mathrm{~km}$. It is not possible to compare the depth values obtained in this study with those given by the CMT method, because it is necessary to take in account that the minimum depth obtained from CMT is $15 \mathrm{~km}$. The CMT method has no resolution at shallow depth.

We have obtained a velocity rupture of $1.5 \mathrm{~km} / \mathrm{s}$ from the directivity function of the $\mathrm{P}$ waves for 1980 and 1998 events (Fig. 5A and B). This value has been checked by the body-wave inversion process. Similar results have been obtained by Udías (1971) in the study of four earthquakes located on the oceanic ridge, one of them in the Azores (4 July 1966). From Table 3 the error bar for the rupture velocity can be estimated, but we think that it is not significant.

Focal mechanisms of the three earthquakes studied, together with those obtained by other authors, have been used in order to obtain a seismotectonic model for the Azores region. We are interested in the eastern Azores plateau, the eastern part of the region limited by the bathymetric line $(2000 \mathrm{~m})$. For this reason we consider only the focal mechanisms listed in Table 5 and shown in Fig. 8. These mechanisms have been obtained from waveform inversion, centroid-moment tensor inversion and body-wave polarities.
The strike-slip motion obtained for the 1980 and 1998 earthquakes and normal faulting for the 1997 event are in agreement with the stress regime in the Azores region (Madeira and Ribeiro, 1980). We observe that most of the mechanisms from the triple junction to Terceira Island (mechanisms 1 to 5 in Fig. 8) correspond to strike-slip solutions, with planes trending in NNWSSE and NNE-SSW directions, with the exception of shock 1, which has a normal mechanism. The other earthquakes showing normal faulting $(21,22$ and 24) are located to the north of the Terceira Ridge, far from those with strike-slip character. The 1980 earthquake (event 5 ) is the largest in the studied area (with the exception of the earthquake located at SW of Azores Islands), with a magnitude $M_{\mathrm{w}}=6.8$. One problem for this region is the selection of the fault plane for the 1980 and 1998 shocks (events 5 and 3, respectively). The aftershock distribution obtained for the 1980 event by Hirn et al. (1980) suggested the NNW-SSE as fault plane. For the 1998 shock, Vales et al. (2001) obtained two alignments for the aftershocks, both with same trend as the two planes obtained from the focal mechanism study. In this study, the directivity function showed the NNW-SSE plane as the fault plane for both events, with the rupture propagating to the SSE.

The stress regime deduced from the focal mechanisms of the 1980 and 1998 events show horizontal extension in the $\mathrm{N}-\mathrm{S}$ direction. These results confirm 


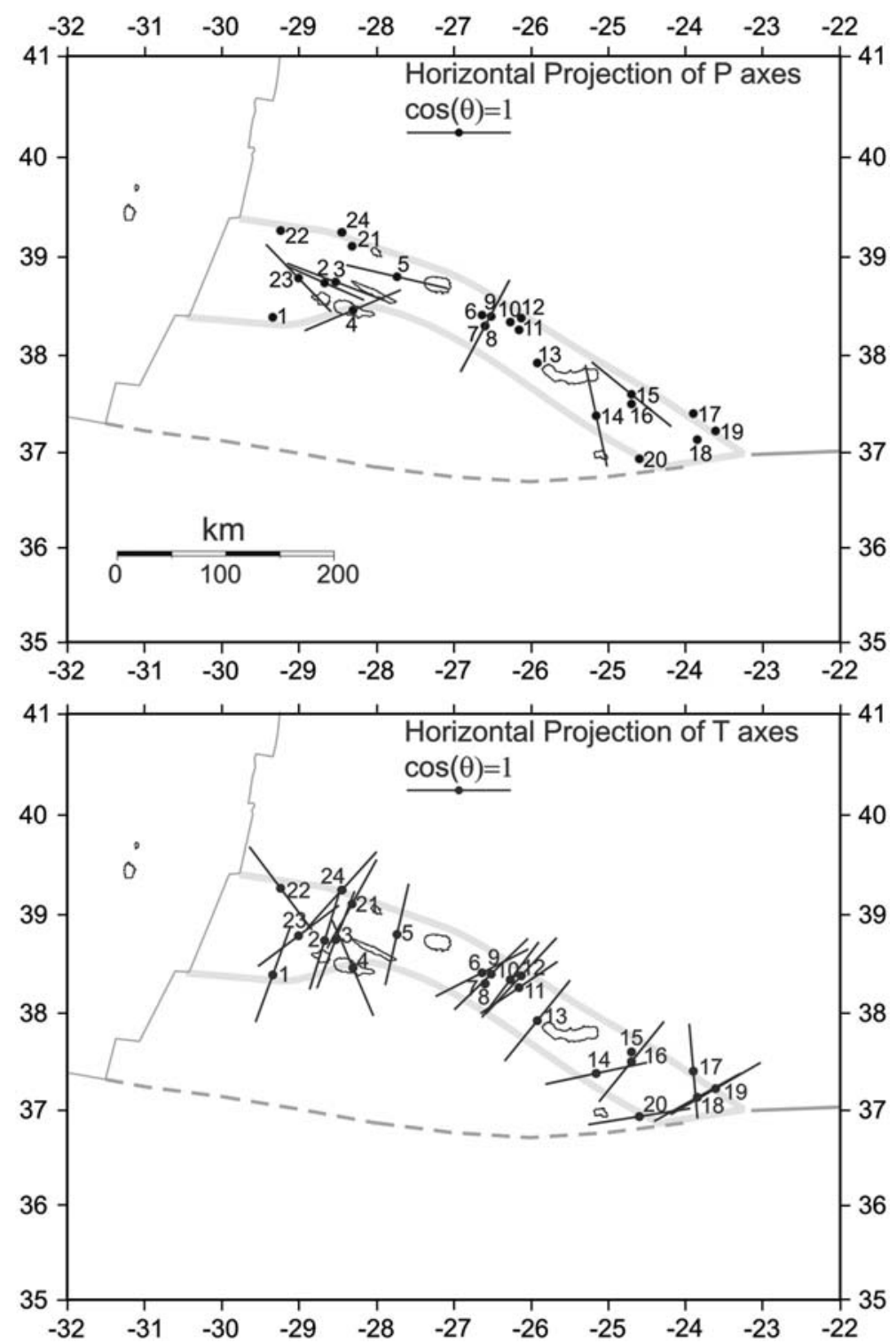

Fig. 9. Horizontal projection of pressure (top) and tension (bottom) axes obtained from focal mechanism parameters of earthquakes listed in Table 5.

previous results obtained by Lourenço et al. (1998), inferred from morphological features.

The 1997 earthquake (event 9), with a mechanism of normal faulting, was located between Terceira Island and the Gloria Fault, in agreement with the focal mechanisms of most earthquakes in this area. Only events 8 and 15 (both with magnitudes less than 5.5) with reverse solutions, and events 7 and 14, with strikeslip solutions, have different focal mechanisms.

A common characteristic of the 1980, 1997 and 1998 earthquakes is the shallow focal depth, less than $10 \mathrm{~km}$, in agreement with the oceanic-type crust.
We have plotted in Fig. 9 the horizontal tension and pressure axes for the earthquakes in the Azores region. For events 6 to 19, we have horizontal extension trending NE-SW, normal to the Terceira Ridge. Only for event 14 do the tension axes have an ENE-WSW trend, but this corresponds to an earthquake with a strike-slip solution. Events 8 and 15, with anomalous reverse faulting mechanisms, show a correct tension axis orientation. To the west of Terceira Island, in events 1 to 5 , the tension axes are also horizontal but we have a rotation in the trend to approximately $\mathrm{N}-\mathrm{S}$. The pressure axis (Fig. 9) shows horizontal compression in an E-W 


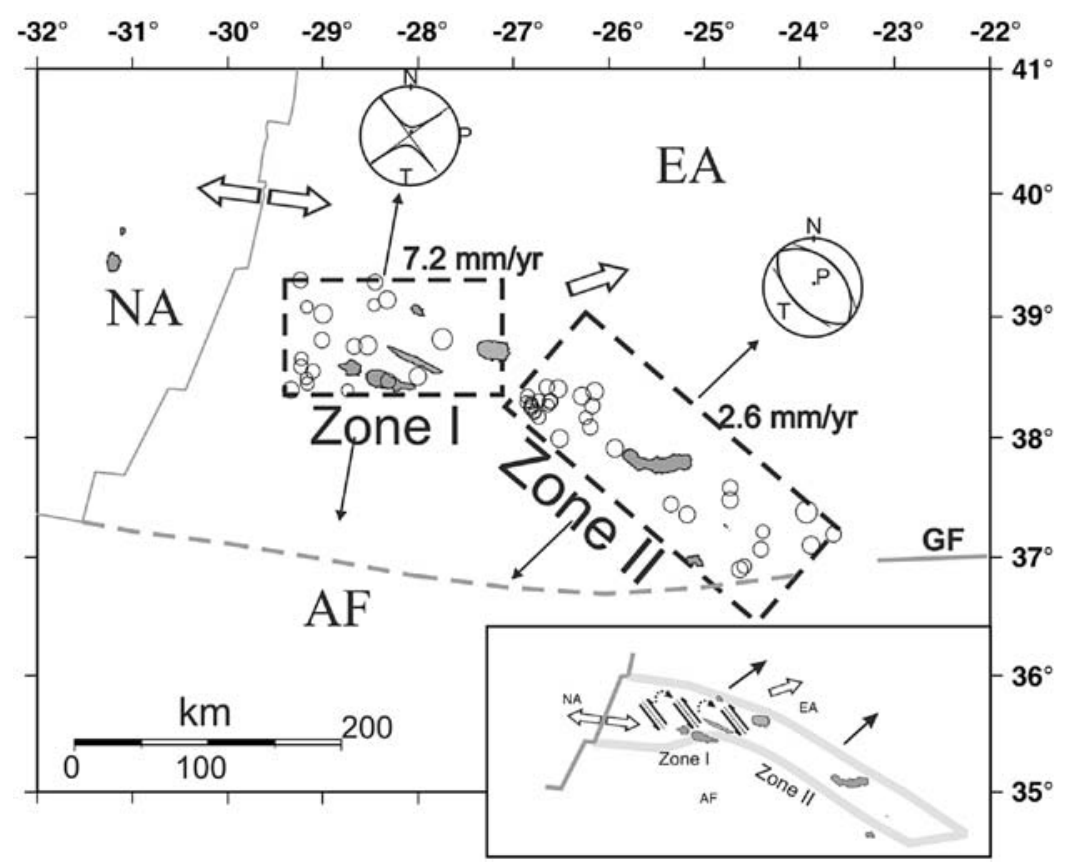

Fig. 10. Seismotectonic for the Azores region. White arrows show relative motion between adjacent plates predicted by Nuvel-1A. Thin arrows show the horizontal extension obtained from the total seismic moment tensor. Dotted arrows show the $T$-axes of the moment tensors. See text for details. Numbers correspond to horizontal velocity obtained from seismological data. NA, AF and EA are as in Fig. 1. The inset represents a sketch of hypothetical distributed deformation model.

direction for events 2 to 5 . For events 7, 8, 14 and 15, the pressure axis is also horizontal, but the compression is approximately $\mathrm{N}-\mathrm{S}$. A change in the stress pattern in the Azores region is clear from Fig. 9.

In order to quantify the results of focal mechanism studies, we have estimated the Frohlich diagram (Frohlich and Apperson, 1992) and the total seismic moment (Figs. 8 and 10). The Frohlich diagram shows that most of the solutions correspond to normal faulting or to strike-slip normal faulting. Only one shock has a purely reverse character (event 8, Fig. 8).

The Frohlich diagram represents all earthquakes with the same weight, independent of their magnitude. In Table 5 and Fig. 8, the 1939 and 1980 shocks have magnitudes $M_{\mathrm{s}} \sim 7$, compared with the other earthquakes with magnitudes between 5.0 and 6.0, and, consequently, it is difficult to quantify the stress regime in the area. A solution is the use of total seismic moment for the area defined as the sum of the moment tensors calculated from individual solutions:

$M_{i j}^{\mathrm{total}}=\underset{\substack{M_{\mathrm{o}} \\ M_{i j}^{k}}}{N} m_{i j}^{k}$

where $N$ is the number of earthquakes, $M_{\mathrm{o}}$ the scalar seismic moment of each event and $m_{i j}$ the seismic moment tensor components. Larger earthquakes with high values of $M_{\mathrm{o}}$ make larger contributions to the estimation of the total seismic moment tensor. Using the solutions of Table 5, by Eq. (1), to we have estimated the components of total $M_{i j}$ for the two regions.

In accordance with our results, we have divided the whole region into two zones: Zone I (events 1 to 5 and 21 to 24) and Zone II (events 6 to 20). In Zone I, the total seismic moment tensor obtained corresponds to strike-slip faulting with horizontal pressure and tension axes in $\mathrm{E}-\mathrm{W}$ and $\mathrm{N}-\mathrm{S}$ direction. The compensated linear vector dipole amount (CLVD amount of non-DC) is $8 \%$, which confirms the focal mechanism represented in Fig. 10 as representative of the faulting in Zone I. For Zone II, the total moment tensor corresponds to normal faulting, with a horizontal tension axis trending to NE-SW, normal to the Terceira Ridge, with a CLVD amount of $12 \%$. The low amount of CLVD obtained for both zones confirms the mechanisms plotted in Fig. 10 as representative of the stress regimes and, consequently, of the change between the two zones.

This rotation of the tension and pressure axis from Zone I to Zone II is in agreement with the results obtained by Lourenço et al. (1998) from morphological features based on the linear volcanic ridge orientations. 
The orientation of the plate motion calculated from Nuvel-1A model (DeMets et al., 1994) is more E-W than the T-axe determined in this study for both Zones (I and II).

From the seismicity and focal mechanisms, we estimated the average slip velocity for Zones I and II, using data from earthquakes with a magnitude $M_{\mathrm{s}} \geq 4.0$ that occurred between 1923 and 2002, in accord with the expression (2) of Buforn et al. (2004):

$\Delta \dot{u}=\frac{\Sigma M_{\mathrm{o}}^{i}}{\mu \mathrm{LWT}}$

where $M_{\mathrm{o}}$ is the total scalar seismic moment, $\mu$ is the rigidity coefficient, LW the fault area and $T$ the period. For shocks for which no estimation of seismic moment $M_{\mathrm{o}}$ had been made, an empirical relation (3) between $M_{\mathrm{o}}$ and $M_{\mathrm{s}}$ was derived for Azores earthquakes greater than $M_{\mathrm{s}}=4.4$ (Borges, 2003) for the instrumental period (1973-1997) (ISC catalogue):

$\log M_{\mathrm{o}}=1.1 M_{\mathrm{s}}+11.7$

The period selected (1923-2002) deals with the twentieth century which is characterized by i) the development of instrumental seismology, ii) the adequate seismological services and iii) the significant strongest earthquakes occurred during this period. The average rate of slip $\Delta \dot{u}$ for the period $T=79$ years can be estimated directly from Eq. (2) with $\mu=3.3 \times 10^{11}$ dyn $\mathrm{cm}^{-2}$. The area was estimated using $L_{\mathrm{I}}=172 \mathrm{~km}$ and $L_{\mathrm{II}}=250 \mathrm{~km}$ in length, respectively, for Zone I and Zone II, as suggested by the seismicity distribution reported in Fig. 10 , and a width $W_{\mathrm{I}}=10 \mathrm{~km}$ and $W_{\mathrm{II}}=14 \mathrm{~km}$ in $10 \mathrm{~km}$ thick layer, as suggested by an average dip angles of $90^{\circ}$ (strike-slip character) and $45^{\circ}$ (normal character), respectively, for Zone I and Zone II. We obtain values of rate of seismic slip for Zone I and Zone II of $7.2 \mathrm{~mm} / \mathrm{yr}$ and $2.6 \mathrm{~mm} / \mathrm{yr}$, respectively (Fig. 10), which corresponds to horizontal extensional rate of $1.8 \mathrm{~mm} / \mathrm{yr}$ in Zone II in a N46E direction as deduced from the total seismic moment tensor. In the Zone I the relation between strain rate and relative plate movement is more difficult since strain release occurs essentially by strikeslip movement. Nevertheless if we consider that Zone I is a large area of deformation confined by the EA and AF plates, were the movement between them is accommodated by block rotation (McKenzie and Jackson 1986), we could conclude that for this Zone the deformation is accommodated by seismic strain with an extensional component of movement in a N53E direction as deduced from the total seismic moment tensor. The value of the horizontal extensional rate, for the Zone I, depends on an appropriate distributed deformation model (McKenzie and Jackson 1986; Fig. 10), which is not the purpose of this work.

The average seafloor spreading rate for the whole of the region (Zones I and II) is $4.4 \mathrm{~mm} / \mathrm{yr}$, similar to the value $(\sim 4.2 \mathrm{~mm} / \mathrm{yr})$ obtained from GPS data (Fernandes, 2004; McClusky et al., 2003). The value supported by the relative rate of motions $(\sim 4.5 \mathrm{~mm} /$ yr) predicted by the Nuvel-1A model (DeMets et al., 1994) in the central and eastern islands of Azores. A difference between the direction of extension obtained in this work (toward N53E and N46E in Zone I and II, respectively) and that predicted by Nuvel-1A (toward $\mathrm{N71E}$ ) is found. Other displacement is caused by a seismic processes, in the form of folding, thickening, plastic deformation or slow slip, which is not included in our estimation. This means that seismic strain analyses may underestimate the geological deformation. Owing to the uncertainty we have about large historical earthquakes (Table 1), we have used only the instrumental period in this estimation.

The adequacy of seismic catalogues to estimate earthquake recurrence rate depends on the area of the region, catalogue duration, and regional strain rate (Ward, 1998). To define a catalogue adequacy parameter Aasha et al. (2006) suggested that we consider the product of the duration of the earthquake record, the area of the region and the average strain rate, as estimated by space geodetic methods. Given the shortness of the catalogue duration and variability in absolute rate, we do not necessarily expect spatial similarity between geodetic deformation and seismicity. We do not attempt in this article to revise seismic estimates for Azores region. However, analysis of seismic versus aseismic deformation in the Azores region inferred from earthquakes and geodetic data is an interesting study that we suggest for future work.

\section{Conclusions}

From the body-wave inversion we have obtained similar focal mechanisms for the 1980 and 1998 earthquakes, with left-lateral strike-slip faulting, foci at shallow depth, between 5 and $7 \mathrm{~km}$, and scalar seismic moment of $1.9 \times 10^{19} \mathrm{Nm}$ and $1.4 \times 10^{18} \mathrm{Nm}$, respectively. The NNW-SSE plane corresponds to the rupture plane with rupture propagating to the south. These results are in agreement with the study of the directivity function of LR waves and distribution of aftershocks. For the 1997 shock, we have obtained a 
mechanism of normal faulting, with the rupture process in three steps, and focal depths between 5 and $7 \mathrm{~km}$. Our total scalar seismic moment was $7.0 \times 10^{17} \mathrm{Nm}$, with source time duration about $5 \mathrm{~s}$.

We found two types of behaviour present along the region; it can be divided into two zones: Zone I (from $30^{\circ} \mathrm{W}$ to $27^{\circ} \mathrm{W}$ ) and Zone II (from $27^{\circ} \mathrm{W}$ to $23^{\circ} \mathrm{W}$ ) with a change in the seismicity. Zone I is oriented ENE-WSW, and Zone II, NW-SE. Earthquakes located in Zone I show a predominant strike-slip motion with horizontal extension in a N-S to NNE-SSW direction and horizontal EW compression. For the 1980 and 1998 shocks, in Zone I, the Terceira Ridge is oriented NE-SW and this direction corresponds to the fault plane. In Zone II, we have found a horizontal extension in a NE-SW direction, normal to the Terceira Ridge. The change in the stress direction in the Azores region is based on all the available seismological data and shows the complexity of the region. The increased number of focal mechanisms for the region now shows this complexity. We see this different pattern in the velocities estimated from seismic data for Zones I and II, faster strain rate with strike-slip movement in Zone I, $7.2 \mathrm{~mm} / \mathrm{yr}$, compared with normal faulting, $2.6 \mathrm{~mm} / \mathrm{yr}$ of strain rate and $1.8 \mathrm{~mm} / \mathrm{yr}$ of horizontal extension rate, in Zone II. The deformation of Azores region is accommodated by an average seismic strain rate of about $4.4 \mathrm{~mm} / \mathrm{yr}$, in a NW direction.

\section{Acknowledgements}

The authors wish to express their gratitude for the valuable comments and discussion provided by Dr. L. Drake. This manuscript was greatly improved by the critical review and comments of Professor Luis Matias from the University of Lisbon. This work has been supported in part by the Ministério da Ciência e Tecnologia PRODEP/doutoramentos (Portugal) and with the support of the Fundação para a Ciência e a Tecnologia (Portugal), through projects FCT/POCTI/CTE-GIN/ 59994/2004, FCT/POCTI/CTE-GIN/59750/2004, by Ministerio de Ciencia y Tecnologia (Spain), project REN03-5178, and by CGE project SEISMOLITOS (Portugal).

\section{References}

Aasha, P., Anderson, J.G., Kremer, C., 2006. Comparison of seismic and geodetic scalar moment rates across the Basin and Range Province. Bull. Seismol. Soc. Am. 96 (1), 11-32.

Anderson, D.L., 2005. Scoring hot spots: the plume and plate paradigms. In: Foulger, G.R., Natland, J.H., Presnall, D.C., Anderson, D.L. (Eds.), Plates, Plumes, and Paradigms. Geol. Soc. Am., Special Volume 388, pp. 31-54.
Asimow, P.D., Dixon, J.E., Langmuir, C.H., 2004. A hydrous melting and fractionation model for mid-ocean ridge basalts: application to the Mid-Atlantic Ridge near the Azores. Geochem. Geophys. Geosyst. 5 (1), Q01E16. doi:10.1029/2003GC000568.

Ben-Menahem, A., 1961. Radiation of seismic surface-waves from finite moving sources. Bull. Seismol. Soc. Am. 51, 401-435.

Bezzeghoud, M., 1987. Inversion et analyse spectrale des ondes P. Potentialité des données numériques large bande. Application à des séismes méditerranéens. Ph.D thesis, Université Paris VII, $232 \mathrm{pp}$.

Bezzeghoud, M., Buforn, E., 1999. Source parameters of 1992 Melilla (Spain, $M_{w}=4.8$ ), 1994 Alhoceima (Morocco, $M_{w}=5.8$ ) and 1994 Mascara (Algeria, $M_{w}=5.7$ ) earthquakes and seismotectonic implications. Bull. Seismol. Soc. Am. 89 (2), 359-372.

Bird, P., 2003. An updated digital model of plate boundaries. Geochem. Geophys. Geosyst. 4 (3), 1027. doi:10.1029/2001GC000252 ftp:// element.ess.ucla.edu/PB2002/.

Borges, J., 2003 Fonte sísmica em Portugal. Algunas implicaçoes na Geodinâmica Açores-Gibraltar. PhD, University of Evora, Portugal, $307 \mathrm{pp}$.

Brillinger, D., Udías, A., Bolt, B.A., 1980. A probability model for regional mechanism solutions. Bull. Seismol. Soc. Am. 70, 149-170.

Brune, J.N., 1970. Tectonic stress and the spectra of seismic shear waves from earthquakes. J. Geophys. Res. 75, 4997-5009.

Buforn, E., Jimenez, M.J., Udías, A., 1983. Parámetros focales de los terremotos de 26 de Mayo de 1975 y 1 de Enero de 1980 en la región de Azores-Gibraltar y sismotectónica regional. Rev. Geofís. $39,51-63$.

Buforn, E., Udías, A., Colombás, M.A., 1988. Seismicity, source mechanisms and seismotectonics of the Azores-Gibraltar plate boundary. Tectonophysics 152, 89-118.

Buforn, E., Bezzeghoud, M., Udías, A., Pro, C., 2004. Seismic sources on the Iberia-African plate boundary and their tectonic implications. Pure Appl. Geophys. 161, 623-646.

Christensen, H., Ruff, L.J., 1985. Analysis of the trade-off between hypocentral depth and source time function. Bull. Seismol. Soc. Am. 75 (6), 1637-1656.

DeMets, C., Gordon, R., Argus, D., Stein, S., 1994. Effect of recent revisions to the geomagnetic reversal time scale on estimates of current plate motions. Geophys. Res. Lett. 21, 2191-2194.

Fernandes, R.M.S., 2004. Present-day kinematic at the AzoresGibraltar plate boundary as derived from GPS observations. $\mathrm{PhD}$ University Delft, 202 pp.

Fernandes, R.M.S., Miranda, J.M., Catalao, J., Luis, J.F., Bastos, L., Ambrosius, B., 2002. Coseismic displacements of the $M_{\mathrm{w}}=6.1$, July 9, 1998, Faial earthquake (Azores, North Atlantic). Geophys. Res. Lett. 29 (16), 21/1-21/4.

Frohlich, C., Apperson, K.D., 1992. Earthquake focal mechanisms, moment tensors and consistency of seismic activity near plate boundaries. Tectonics 11, 279-296.

Grimison, N., Chen, W., 1988. The Azores-Gibraltar plate boundary: focal mechanisms, depths of earthquakes and their tectonic implications. J. Geophys. Res. 91, 2029-2047.

Hirn, A., Haessler, J., Hoang Trong, P., Wittlinger, G., Mendes Victor, L., 1980. Aftershock sequence of the January 1st, 1980 earthquake and present-day tectonics in the Azores. Geophys. Res. Lett. 7, 501-504.

Kanamori, H., 1978. Quantification of earthquakes. Nature 271, 411-414.

Kanamori, H., Anderson, D.L., 1975. Theoretical basis of some empirical relations in seismology. Bull. Seismol. Soc. Am. 65, 1073-1095. 
Kikuchi, A., Kanamori, H., 1991. Inversion of complex waves III. Bull. Seismol. Soc. Am. 81, 2335-2350.

Krause, D.C., Watkins, N.D., 1970. North Atlantic crustal genesis in the vicinity of the Azores. Geophys. J. R. Astron. Soc. 19, 261-283.

López Arroyo, A., Udías, A., 1972. Aftershock sequence and focal parameters of the February 28, 1969 earthquake of AzoresGibraltar fracture zone. Bull. Seismol. Soc. Am. 62, 699-720.

Lourenço, N., Miranda, J.M., Luis, J.F., Ribeiro, A., Mendes Victor, L., Madeira, J., Needham, D., 1998. Morpho-tectonic analysis of the Azores Volcanic Plateau from a new bathymetric compilation of the area. Mar. Geophys. Res. 20, 141-156.

Luis, J.F., 1996. Le Plateau des Açores et le triple point associé: analyse géophysique et evolution. PhD Université Denis Diderot, Paris VII, $201 \mathrm{pp}$.

Luis, J.F., Miranda, J.M., Galdeano, A., Patriat, P., Rossignol, J.C., Mendes Victor, L., 1994. The Azores triple junction since $10 \mathrm{Ma}$ from an aeromagnetic survey of the Mid-Atlantic Ridge. Earth Planet. Sci. Lett. 125, 439-459.

Machado, F., Silveira, E., 1982. O terremoto de 1 Jan. 1980 e a tectónicas dos Açores. Açoreana 6, 155-170.

Madeira, J., Ribeiro, A., 1980. Geodynamics models for the Azores triple junction: a contribution from tectonics. In: Boillot, G., Fontboté, J.M. (Eds.), Alpine Evolution of Iberia and its Continental Margins. Tectonophysics, vol. 184, pp. 405-415.

Madureira, P., Moreira, M., Mata, J., Allègre, C.J., 2005. Primitive neon isotopes in Terceira Island (Azores archipelago). Earth Planet. Sci. Lett. 233, 429-440.

McClusky, S., Reilinger, R., Mahmoud, S., Ben Sari, D., Tealeb, B., 2003. GPS constraints on Africa Nubia and Arabian plate motions. Geophys. J. Int. 1, 126-138.

McKenzie, D., 1972. Active tectonics of the Mediterranean region. Geophys. J. R. Astron. Soc. 30, 109-185.

McKenzie, D.P., Jackson, J.A., 1986. A block model of distributed deformation by faulting. J. Geol. Soc. Lond. 143, 349-353.

Miranda, J.M., Mendes Victor, L., Simoes, J.Z., Luis, J.F., Matías, L., Shimamura, H., Shiobara, H., Nemoto, H., Mochizuki, H., Hirn, A., Lepine, J.C., 1998. Tectonic setting of the Azores Plateau deduced from OBS survey. Mar. Geophys. Res. 20, 171-182.

Montagner, J.-P., Ritsema, J., 2001. Interactions between ridges and plumes. Science 294, 1472-1473.

Montelli, R., Nolet, G., Dahlen, F.A., Masters, G., Engdal, E. Robert, Hung, S.-H., 2004. Finite-frequency tomography reveals a variety of plumes in the mantle. Science 303 (5656), 338-343.

Moreira, V.S., 1985. Seismotectonics of Portugal and its adjacent area in the Atlantic. Tectonophysics 117, 85-96.

Nakanishi, I., Kanamori, H., 1984. Source mechanisms of twenty-six large, shallow earthquakes $\left(M_{\mathrm{s} \_} 6.5\right)$ during 1980 from P-wave first motion and long-period Rayleigh wave data. Bull. Seismol. Soc. Am. 74, 805-818.

Nunes, J.C., Ribeiro, E., 2001. Caracterizaçao da sismicidade instrumental dos Açores no periodo 1950-1980. SISMICA, Encontro Nacional de Sismología e Enghenaria Sísmica, Açores.

Pro, C., 2002. Estudio del efecto de directividad en la forma de ondas. PhD Universidad Complutense, Madrid, 259 pp.

Schilling, J.G., 1975. Azores mantle blob: rare earth evidence. Earth Planet. Sci. Lett. 25, 103-115.

Searle, R., 1980. Tectonic pattern of the Azores spreading centre and triple junction. Earth Planet. Sci. Lett. 51, 415-434.

Senos, M.L., Gaspar, J.L., Cruz, J., Ferreira, T., Nunes, J.C., Pacheco, J.M., Alves, P., Queiroz, G., Dessai, P., Coutinho, R., Vales, D., Carrilho, F., 1998. O terramoto do Faial de 9 de Julho de 1998. $1^{\circ}$ Simpósio de Meteorologia e Geofísica da APMG, pp. 61-67.

Silveira, G., Stutzmann, E., Davaille, A., Montagner, J.-P., MendesVictor, L., Sebai, A., 2006. Azores hotspot signature in the upper mantle. J. Volcanol. Geotherm. Res. 156, 23-34.

Tanioka, Y., Ruff, L., 1997. Source time functions. Seismol. Res. Lett. 68, 386-397.

Udías, A., 1971. Source parameters of earthquakes from spectra of Rayleigh waves. Geophys. J. R. Astron. Soc. 22, 353-376.

Udías, A., 1980. Seismic stresses in the region Azores-Spain-Western Mediterranean. Rock Mech. 9, 75-84.

Udías, A., Buforn, E., 1988. Single and joint fault-plane solutions from first motion data. In: Doorbons, D. (Ed.), Seismological Algorithms. Academic Press, London, pp. 443-453.

Udías, A., López Arroyo, A., Mézcua, J., 1976. Seismotectonics of the Azores-Alboran region. Tectonophysics 31, 259-289.

U.S. Department of Commerce, National Oceanic and Atmospheric Administration, National Geophysical Data Center, 2001. 2-minute Gridded Global Relief Data (ETOPO2). http:// www.ngdc.noaa.gov/mgg/fliers/01mgg04.html.

Vales, D.L., Matías, L., Carrilho, F., Madeira, J., Morais, I., Senos, L., 2001. Relocalizaçao hipocentral e mecanismos focais da sequencia sismica que se seguiu ao sismo do Faial em 1998. $2^{\circ}$ Simposium de Meteorología e Geofísica, pp. 56-63. APMG.

Vogt, P.R., Jung, W.Y., 2004. The Terceira Rift as hyper-slow, hotspotdominated oblique spreading axis: a comparison with other slowspreading plate boundaries. Earth Planet. Sci. Lett. 218, 77-90. doi:10.1016/S0012-821X(03)00627.

Ward, S.N., 1998. On the consistency of earthquake moment rates, geological fault data, and space geodetic strain: the United States. Geophys. J. Int. 134, 172-186.

Zhang, Y.-S., Tanimoto, T., 1992. Ridges, hotspots and their interaction as observed in seismic velocity maps. Nature $355,45-49$. 